\title{
New and little known species of Lepechinella (Crustacea, Amphipoda, Lepechinellidae) and an allied new genus Lepesubchela from the North Atlantic
}

\author{
Per-Otto JOHANSEN ${ }^{1 *}, \&$ Wim VADER ${ }^{2}$. \\ ${ }^{1}$ Uni Research Environment - Section of Applied Environmental Research - marine. High Technology \\ Centre in Bergen, Norway. \\ * Corresponding author: per-otto.johansen@uni.no \\ ${ }^{2}$ Tromsø Museum, University of Tromsø, 9037 Tromsø, Norway. \\ E-mail:wim.vader@uit.no \\ 1 urn:1sid:zoobank.org:author:D8F8DD04-6F26-4CC0-B98A-E8E068C38A09 \\ ${ }^{2}$ urn:1sid:zoobank.org:author:92E60D63-E003-466F-A155-F526B851B9CB
}

\begin{abstract}
New species of Lepechinella, L. norvegica sp. nov. and L. victoriae sp. nov., from the North East Atlantic are described together with the new, closely related genus and species Lepesubchela christinae gen. et sp. nov. Lepechinella arctica Schellenberg, 1926 from north of Spitsbergen and Lepechinella schellenbergi Stephensen, 1944 from Greenland are redescribed. A key to the species of Atlantic and Arctic Lepechinella is provided. Descriptions of taxonomic characters from related species in the Atlantic and Arctic are discussed.
\end{abstract}

Key words. Crustacea, Amphipoda, Lepechinellidae, North Atlantic, Arctic.

Johansen P.O. \& Vader W. 2015. New and little known species of Lepechinella (Crustacea, Amphipoda, Lepechinellidae) and an allied new genus Lepesubchela from the North Atlantic. European Journal of Taxonomy 127: 1-35. http://dx.doi.org/10.5852/ejt.2015.127

\section{Introduction}

Stebbing (1908) named the amphipod genus Lepechinella (after the Russian author Lepechin who described a White Sea amphipod as early as 1780) for a species he collected at a depth of 850-900 meters off the Orkney Islands, Scotland. More than 30 species have so far been described in the genus Lepechinella (Barnard 1973; Barnard \& Karaman 1991; Sittrop \& Serejo 2009). The genus has a cosmopolitan distribution and contains mainly deepwater species on soft bottoms; some of the species occur in the hadal trenches of the deep sea (Kamenskaya 1995). Lepechinellids are well adapted to a demersal or epibenthic lifestyle on soft substrates in deep water (Barnard 1973).

Several Lepechinella species have previously been reported from the North Atlantic and Arctic. Schellenberg (1925) described material he named Dorbanella sp. from 1000 meters deep, north of Svalbard, but later (Schellenberg 1926, footnote) realized that this was a Lepechinella, and named it $L$. 
arctica. Stephensen (1944) reported on material from W. Greenland, which he considered to be the same as Schellenberg's material, but having overlooked Schellenberg's 1926 paper, coined the new name L. schellenbergi. Eupraxie Gurjanova (1951) also thought she had L. arctica from the deep Greenland Basin; her material has later been renamed L. eupraxiella by Barnard (1973). Three species, L. helgi, L. grimi and L. skarphedini were caught in 1971 in epibenthic sledge hauls in the East Iceland Basin (2700 meters) and described as new species by Thurston (1980a,b). Further Atlantic species are L. echinata from 4380 meters in the Bay of Biscay (Chevreux 1914) and L. manco from 843 meters in the Central Mediterranean (Barnard 1973). Sittrop \& Serejo (2009) described three new species from the Campos Basin, Brazil, and provided a key to Lepechinella species of the South Atlantic.

In the present paper, new species of Lepechinella are described from the North Atlantic, as well as a species in a new genus, Lepesubchela gen. nov., characterized by subchelate peraeopods. The material, described by Schellenberg (1925) and Stephensen (1944), is redescribed here and the differences analyzed. The type localities of North Atlantic and Arctic species are plotted in Fig. 1.

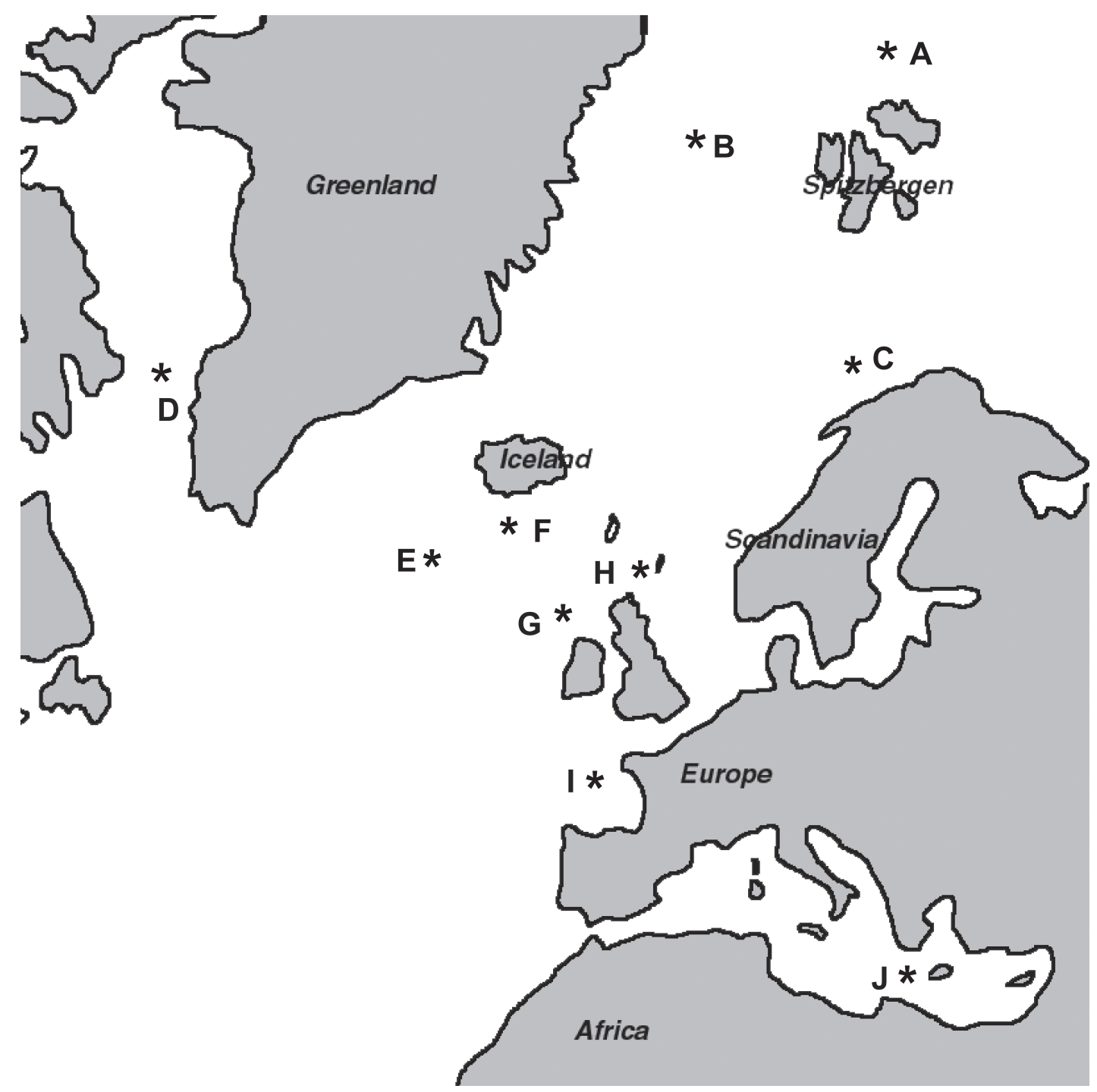

Fig. 1. Type localities of North Atlantic species of Lepechinella and Lepesubchela. A. Lepechinella arctica. B. Lepechinella eupraxiella. C. Lepechinella norvegica sp. nov. D. Lepechinella schellenbergi. E. Lepechinella helgi/skarphedini/grimi. F. Lepechinella victoriae sp. nov. G. Lepesubchela christinae gen. \& sp. nov. H. Lepechinella chrysotheras. I. Lepechinella echinata. J. Lepechinella manco. 
JOHANSEN P.-O. \& VADER W., Lepechinella and Lepesubchela gen. nov. from the North Atlantic

\title{
Material and methods
}

\section{Taxonomic material}

The examined material was collected in the North Atlantic and Arctic. Most of the animals were dissected in glycerol and mounted on microscope slides in Faure's fluid. However, the parts of the holotype of $L$. arctica and also types of $L$. schellenbergi were dissected in ethanol and mounted on microscope slides using Euparal. Drawings were made using stacks of photos taken from a Bresser biolux NG microscope with an electronic sensor and the drawings were made with an electronic pc-tablet using the techniques described by Coleman $(2003,2006,2009)$. The type material of $L$. arctica was borrowed from the Museum für Naturkunde in Berlin and that of L. schellenbergi from the Zoological Museum in Copenhagen. The rest of the type material is kept at the Bergen and Tromsø Zoological Museums.

\section{Definitions}

Seta $=$ flexible structures that are articulated

Spine $=$ rigid structures that are articulated

Tooth $=$ outgrowth that are not articulated

\author{
$\mathrm{A} 1,2=$ Antenna 1,2 \\ Cx 1-7 = Coxal plate 1-7 \\ Ep1-3 = Epimeral plate 1-3 \\ Gn1, 2 = Gnathopod 1,2 \\ Mx1, 2 = Maxilla 1,2 \\ Mxp = Maxilliped \\ P3-P7 = Peraeopod 3-7 \\ U1-3 = Uropod 1-3
}

Abbreviations used in table and figures

\section{Results}

\section{Systematics}

Order Amphipoda Latreille, 1816

Suborder Gammaridea Latreille, 1802

Family Lepechinellidae Schellenberg, 1926

The amphipod Lepechinella chrysotheras, described by Stebbing (1908), was initially placed in the family Paramphithoidae Stebbing, 1906. Unaware of this, Chevreux (1914) described Dorbanella echinata and placed it in the family Tironidae Stebbing, 1906. Schellenberg (1925) described Dorbanella sp. and the family Dorbanellidae. One year later Schellenberg (1926) became aware of the earlier description of a Lepechinella species by Stebbing, and established the family name Lepechinellidae. Later J.L. Barnard (1973) transferred the genera Lepechinella and Paralepechinella Pirlot, 1933 to the family Dexaminidae Leach, 1814. Barnard \& Karaman (1991) included Lepechinella Stebbing, 1908, Lepechinellopsis Ledoyer, 1982, Lepechinelloides Thurston, 1980 and Paralepechinella Pirlot, 1933 in the family Dexaminidae. Andres \& Brandt (2001) revalidated the status of family Lepechinellidae. Sittrop \& Serejo (2009) gave a more extensive historical review of lepechinellid systematics.

\section{Diagnosis}

Andres \& Brandt's diagnosis of Lepechinellidae from 2001 is based on the publications of Schellenberg (1926), J.L. Barnard (1970, 1973) and Bousfield \& Kendall (1994): "Diagnosis: Body processiferous dorsomedially (variable), and/or covered with setae/spines. One to all coxal plates of peraeopods 1-4 
acutely pointed distally, sometimes bifid. Ursomites 2 and 3 separate to completely fused. Accessory flagellum one- or two-articulate. Mandibular molar and palp present. Lower lip with inner lobes. Maxilla 2: inner plate without oblique row of setae. Peraeopods slender, elongate; peraeopods $5-7$ similar, bases linear. Oostegites narrow. Rami of uropods styloid; uropod 3 outer ramus with tiny article 2. Telson normally excavate, lobes usually gaping widely."

\section{Variations}

Rostrum present (e.g., Lepechinella) or lacking (e.g., Lepechinelloides); cephalic teeth present (e.g., Lepechinella) or lacking (Lepechinelloides, Paralepechinella); urosome segments 2 and 3 separate (Lepechinella wolffi) to completely fused (e.g., Lepechinella echinata, L. drygalskii and L. curvispina, Paralepichinella spp.); mandibular molar triturative (Lepechinella, Paralepechinella) or non-triturative (Lepechinelloides, Lepechinellopsis); mandibular palp three-articulate (Lepechinella, Lepechinellopsis, Paralepechinella) or one-articulate (Lepechinelloides); uropods 1-3 outer rami reduced (Lepechinellopsis); telson cleft distally (Paralepechinella longipalpa Pirlot, 1933).

\section{Type genus}

Lepechinella Stebbing, 1908

The genera included in Lepechinellidae are: Lepechinella Stebbing, 1908; Paralepechinella Pirlot, 1933; Lepechinelloides Thurston, 1980a; Lepechinellopsis Ledoyer, 1982. This paper also includes a new genus called Lepesubchela gen. nov. The type species of this genus is among others characterized by strongly subchelate peraeopods 6 and 7 .

\section{Key to the genera of Lepechinellidae}

1. Mandible palp 1-articulate

Lepechinelloides Thurston, 1980

- Mandible palp 3-articulate

2. Peraeopods 6 and 7 clearly subchelate Lepesubchela (gen. nov.)

- Peraeopods 6 and 7 simple

3. Mandible palp with article 3 extremely long, longer than 10x article 2 ...Paralepechinella Pirlot, 1933

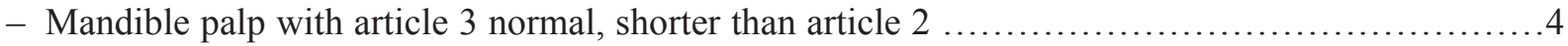

4. Uropods $1-3$ with outer ramus strongly reduced, shorter than $1 / 3$ of inner ramus

- Uropods 1-3 with outer ramus normal Lepechinella Stebbing, 1908

Genus Lepechinella Stebbing, 1908

Lepechinella Stebbing, 1908: 344-346, plate XVI.

Dorbanella Chevreux, 1914: 1-4, figs 1-3.

\section{Diagnosis}

The characters given in the diagnosis of the genus Lepechinella by Sittrop \& Serejo (2009: 475) are: "Body with projections on the dorsal midline; cephalic tooth divided into two cusps pointed anteriorly; upper lip bilobate; mandible with palp, article 2 of palp of mandible longer than article 3 , incisor process dentate, lacinia mobilis dentate, molar triturative; article 2 of palp of maxilla 1 expanded distally; inner plate of maxilla 2 narrower than outer plate; article 2 of palp of maxilliped longer than articles 1 and 3 combined; peraeopods 3 to 7 slender, all articles elongated, except for article 3 ". 
JOHANSEN P.-O. \& VADER W., Lepechinella and Lepesubchela gen. nov. from the North Atlantic

\section{Key to the species of Atlantic and Arctic Lepechinella}

1. Peraeon segment 1 without dorsal teeth .2

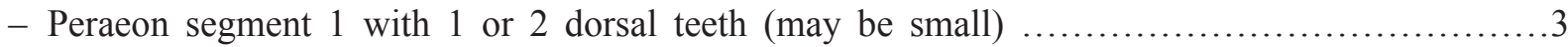

2. Coxal plate 3 clearly bifid; peraeon segment 4 with dorsal tooth

L. campensis Sittrop \& Serejo, 2009. Campos Basin slope, coast of Brazil

- Coxal plate 3 not bifid; peraeon segment 4 dorsally smooth

L. laurensi Sittrop \& Serejo, 2009. Campos Basin slope, coast of Brazil

3. Peraeon segment 1 with a single dorsal tooth ...L. skarphedini Thurston, 1980. East Iceland Basin

- Peraeon segment 1 with 2 dorsal teeth (may be small)

.4

4. Dorsal teeth on peraeon segment 1 small .5

- Dorsal teeth on peraeon segment 1 well-developed ........................................... 6

5. Gnathopod 1 very slender, carpus much longer than propodus; not heavily setose dorsally L. grimi Thurston, 1980. East Iceland Basin

- Gnathopod 1 moderately slender, carpus and propodus subequal in length. Heavily setose along dorsal midline ...L. hirsuta Sittrop \& Serejo, 2009. Campos Basin slope, coast of Brazil

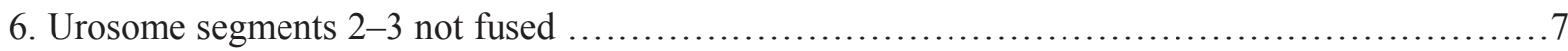

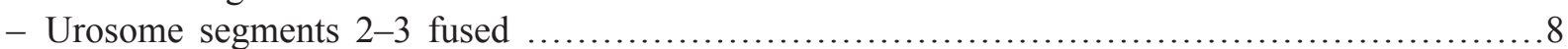

7. Coxal plate 1 bifid, both lobes with serration; Pleon segments 1-3 with 1 large and 1 smaller dorsal tooth .............. eupraxiella (Barnard, 1973). Between Spitzbergen and Greenland

- Coxal plate 1 bifid, both lobes with smooth margins; Pleon segments 1-3 with one large and two smaller dorsal teeth .........L. chrysotheras Stebbing, 1908, North of British Isles

8. Coxal plate 1 long, acute, not bifid ............... echinata Chevreux, 1914. Bay of Biscay

- Coxal plate 1 clearly bifid ................................................................ 9

9. Pleon segments $1-3$ with one large dorsal tooth only ......L. victoriae sp. nov., South of Iceland

- Pleon segments 1-3 with additional dorsal teeth, besides the large posterior one .................10

10. Pleon segments $1-3$ with several smaller teeth (or humps) besides the large posterior one ......11

- Pleon segments 1-3 with one smaller tooth (or hump) besides the large posterior one .........12

11. Coxal plate 3 clearly bifid, with posterior lobe small, but acute. Uropod 1 rami subequal L. manco Barnard, 1973. Mediterranean

- Coxal plate 3 acute, posterior lobe vestigial. Uropod 1 inner ramus clearly shorter $(65 \%)$ than outer ramus L. helgii Thurston, 1980. East Iceland Basin

12. Coxal plate 4 , width $2 \mathrm{x}$ the width of basis

L. norvegica sp. nov.

- Coxal plate 4 , width $3-4 x$ the width of basis .13

13. Peraeopod 7 carpus $1.2 x$ propodus, coxal plate 7 posterodistal corner rounded, posterior margin of peraeopod 7 basis with spines ......L. schellenbergi Stephensen, 1944, Western Greenland

- Peraeopod 7 carpus is $1.6 \mathrm{x}$ propodus, coxal plate 7 parallelogram shaped with acute posterodistal corner, posterior margin of peraeopod 7 basis with setae.

L. arctica (Schellenberg, 1926), Arctic Polar Basin 
The most important differences between L. arctica, L. schellenbergi and L. norvegica sp. nov. are shown in Table 1.

Table 1. Characters that separate Lepechinella arctica Schellenberg, 1926, L. schellenbergi Stephensen, 1944 and L. norvegica sp. nov.

\begin{tabular}{|c|c|c|c|}
\hline & L. norvegica sp. nov. & L. schellenbergi & L. arctica \\
\hline Body & $\begin{array}{l}\text { Many long dorsal/lateral setae } \\
\text { and spines }\end{array}$ & $\begin{array}{l}\text { Some long dorsal/lateral setae } \\
\text { and spines }\end{array}$ & $\begin{array}{l}\text { Few long dorsal/lateral setae } \\
\text { and spines }\end{array}$ \\
\hline Head & Postantennal corner rounded & Postantennal corner rounded & $\begin{array}{l}\text { Postantennal corner acute } \\
\text { according to drawing and text } \\
\text { by Schellenberg }(1925)\end{array}$ \\
\hline $\mathrm{Md}$ & $\begin{array}{l}\text { Md palp art.3 subequal to } \\
\text { art.1. Palp art. } 2 \text { with } 12 \text { setae } \\
\text { and art.3 with } 7 \text { setae. Molar } \\
\text { elliptic with small ribs along } \\
\text { margins }\end{array}$ & $\begin{array}{l}\text { Md palp art. } 1 \text { is } 1.2 x \text { art. } 3 \text {. } \\
\text { Palp art. } 2 \text { with } 7 \text { setae and } \\
\text { art. } 3 \text { with } 5 \text { setae. Molar } \\
\text { elongated with transversal ribs }\end{array}$ & $\begin{array}{l}\text { Md palp art. } 1>\text { art. } 3 \text { and a } \\
\text { strong molar according to } \\
\text { Schellenberg }(1925)\end{array}$ \\
\hline $\mathrm{Mx} 2$ & $\begin{array}{l}\text { Inner plate narrow ( } 1 / 3 \text { of outer } \\
\text { plate) with apical and lateral } \\
\text { setae }\end{array}$ & $\begin{array}{l}\text { Inner plate width } 1 / 2 \text { of outer } \\
\text { plate, with apical setae }\end{array}$ & $\begin{array}{l}\text { Inner plate half as wide as } \\
\text { outer plate according to } \\
\text { Schellenberg (1925) }\end{array}$ \\
\hline Mxp & $\begin{array}{l}\text { Outer lobe reaches the third } \\
\text { joint of palp }\end{array}$ & $\begin{array}{l}\text { Outer lobe reaches the third } \\
\text { joint of palp }\end{array}$ & $\begin{array}{l}\text { Outer lobe reaches to the last } \\
\text { third of the second joint of } \\
\text { palp according to Schellenberg } \\
(1925)\end{array}$ \\
\hline Gn1 and Gn2 & $\begin{array}{l}\text { Inner edge of dactyl with } \\
\text { notches }\end{array}$ & Inner edge of dactyl smooth & $\begin{array}{l}\text { Inner edge of dactyl smooth } \\
\text { according to Schellenberg } \\
(1925)\end{array}$ \\
\hline $\mathrm{P} 3$ and $\mathrm{P} 4$ & $\begin{array}{l}\mathrm{P} 3 \text { merus } 1.6 \mathrm{x} \text { carpus. Width } \\
\text { of } \mathrm{Cx} 3 \text { and } \mathrm{Cx} 4 \text { is } 2 \mathrm{x} \text { width of } \\
\text { basis }\end{array}$ & $\begin{array}{l}\mathrm{P} 3 \text { merus } 1.4 \mathrm{x} \text { carpus. Coxae } \\
\text { posteriorly produced. Width } \\
\text { of } \mathrm{Cx} 3 \text { and } \mathrm{Cx} 4 \text { is } 3 \mathrm{x} \text { width of } \\
\text { basis }\end{array}$ & $\begin{array}{l}\mathrm{P} 3 \text { merus } 1.9 \mathrm{x} \text { carpus. Coxae } \\
\text { posteriorly produced. Width } \\
\text { of } \mathrm{Cx} 3 \text { and } \mathrm{Cx} 4 \text { is } 4 \mathrm{x} \text { width of } \\
\text { basis }\end{array}$ \\
\hline $\mathrm{P} 6$ and $\mathrm{P7}$ & $\begin{array}{l}\text { Posterior margin of basis with } \\
\text { spines }\end{array}$ & $\begin{array}{l}\text { Posterior margin of basis with } \\
\text { spines }\end{array}$ & $\begin{array}{l}\text { Posterior margin of basis with } \\
\text { setae }\end{array}$ \\
\hline P7 & $\begin{array}{l}\text { Carpus is } 1.3 x \text { propodus. } \\
\text { Posterior corner of } \mathrm{Cx} 7 \\
\text { rounded }\end{array}$ & $\begin{array}{l}\text { Carpus is } 1.2 x \text { propodus. } \\
\text { Posterior corner of } \mathrm{Cx} 7 \\
\text { rounded }\end{array}$ & $\begin{array}{l}\text { Carpus is } 1.6 x \text { propodus. } \\
\text { Cx } 7 \text { parallelogram shaped. } \\
\text { Posterior corner of } \mathrm{Cx} 7 \text { acute }\end{array}$ \\
\hline Gills & $\begin{array}{l}\text { Smooth without distinct } \\
\text { pattern }\end{array}$ & Oblique proximally pleated & $\begin{array}{l}\text { Smooth with a distinct distal } \\
\text { capillary pattern }\end{array}$ \\
\hline Ep 3 & $\begin{array}{l}\text { Female Ep3, posterodistal } \\
\text { angle forming a large sinus }\end{array}$ & $\begin{array}{l}\text { Female Ep3, posterodistal } \\
\text { angle forming a small sinus }\end{array}$ & $\begin{array}{l}\text { Female Ep3, posterodistal } \\
\text { angle forming a large sinus }\end{array}$ \\
\hline $\mathrm{U} 2$ & $\begin{array}{l}\text { Outer ramus } 0.8 \mathrm{x} \text { of inner } \\
\text { ramus }\end{array}$ & $\begin{array}{l}\text { Outer ramus } 0.7 x \text { of inner } \\
\text { ramus }\end{array}$ & - \\
\hline Telson & $\begin{array}{l}4 \text { lateral setae and } 4 \text { dorsal } \\
\text { spines. Telson cleft to } 80 \% \text { of } \\
\text { total length }\end{array}$ & $\begin{array}{l}2 \text { lateral setae. Telson cleft to } \\
50 \% \text { of total length }\end{array}$ & - \\
\hline
\end{tabular}


JOHANSEN P.-O. \& VADER W., Lepechinella and Lepesubchela gen. nov. from the North Atlantic

Lepechinella arctica Schellenberg, 1926

Figs $2-4$

Dorbanella sp. Schellenberg, 1925: 206-207, fig. 6.

Lepechinella arctica Schellenberg, 1926: 394.

Lepechinella sp. Stephensen, 1938: 271-273.

Lepechinella arctica - Barnard 1973: 10. — Barnard \& Karaman 1991: 268-269.

non Lepechinella arctica - Gurjanova 1951: 674-677, fig. 465 (= Lepechinella eupraxiella Barnard, 1973: 17).

\section{Material examined}

\section{Holotype}

Parts from peraeon and pleon (Museum für Naturkunde Berlin: Registration no. 19.848). The species is recorded from the Römer \& Schaudinn Expedition, st. 41, in the Polar Basin north of Nordaustlandet and Spitzbergen, Svalbard, at position $81^{\circ} 20^{\prime} \mathrm{N}, 20^{\circ} 30^{\prime} \mathrm{E}, 1000$ meters, initially named Dorbanella sp. by Schellenberg (1925), but later the name was changed to Lepechinella arctica by Schellenberg (1926).

The description of $L$. arctica is based on new drawings of the peraeon and pleon in addition to the text and the original drawing of the head made by Schellenberg (1925). The urosome was missing in the original sample. Schellenberg (1925) briefly described the mouthparts and made a drawing of the head, but these parts have unfortunately not been found in the collections.

\section{Redescription}

\section{Holotype}

Female with fully developed oostegites, length $5.5 \mathrm{~mm}$ without urosome.

Body. Two mid-dorsal teeth on peraeon segment 1 . Peraeon segments $2-7$ with one dorsal tooth each, a few setae and spines, primarily on the dorsal part. Coxal plates with some spines and thin setae. Coxal plate 1-7 decreasing in height posteriorly. Peraeon segments 1-7 with distinctly developed lobes above the coxal plates.

HEAD (Fig. 2). According to Schellenberg (1925) (translated from German): "Head short, exclusive of the processes not much longer than $1^{\text {st }}$ thorax segment. Rostrum shaped as a heavy, acute, horizontal spine, a little wavy, half as long as $1^{\text {st }}$ joint of antenna 1 . Lateral lobe of head not projecting, but provided with 2 marginal spines; postantennal corner acute. No eyes".

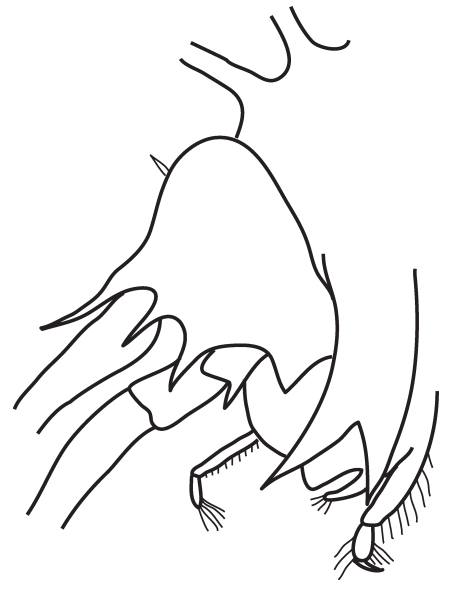

Fig. 2. Lepechinella arctica Schellenberg, 1926 (Dorbanella sp.), head redrawn after Schellenberg (1925). 
MouthPARTS. According to Schellenberg 1925 (translated from German): "Oral parts much projecting. Free margin of upper lip rounded, lateral lobes of lower lip distally rounded; mandibular processes very short and blunt; inner lobes well developed. Mandible strong, molar processes broad; incisor and lacinia mobilis strong and of about equal size, with several blunt teeth; spines long and strong; palp slender,

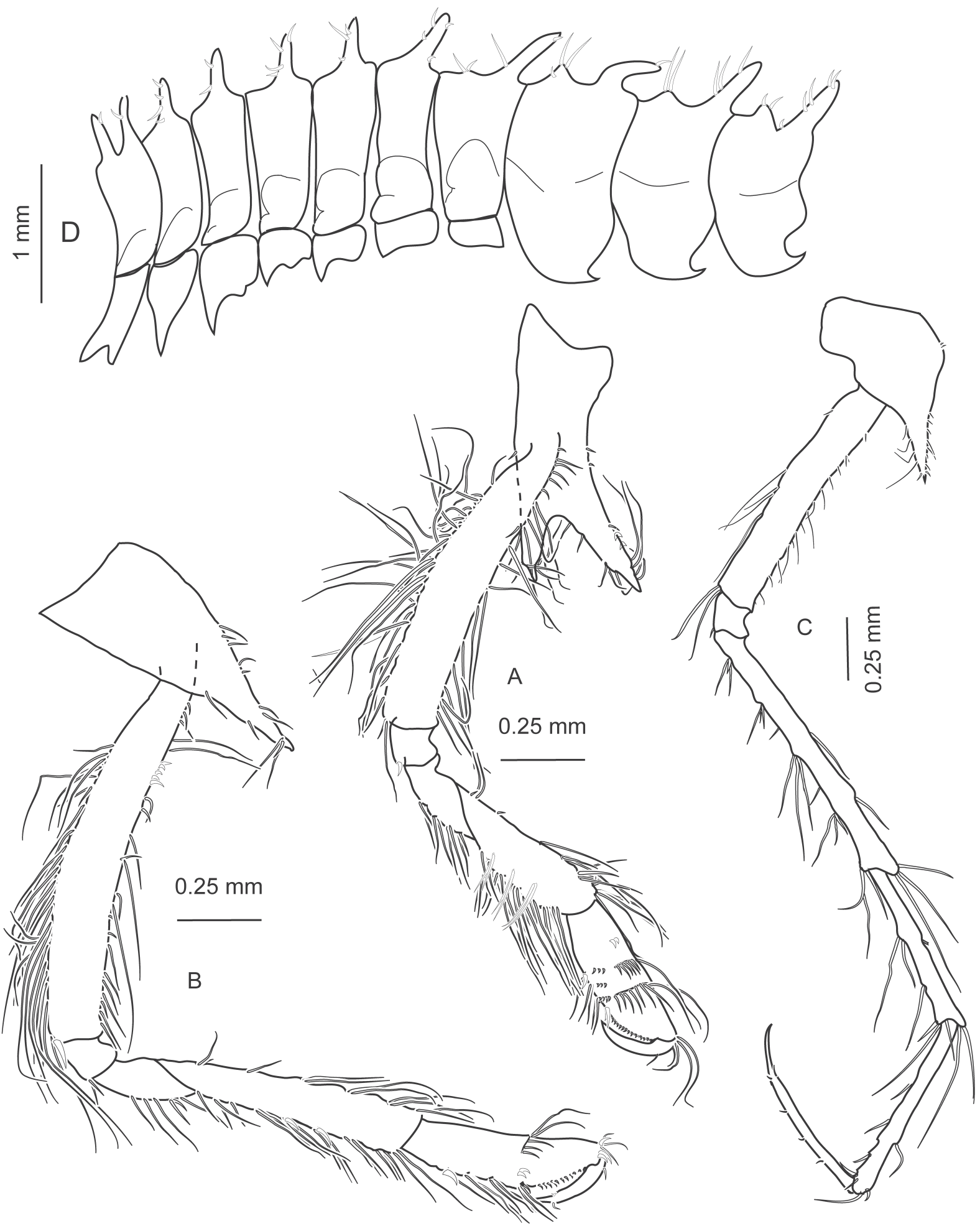

Fig. 3. Lepechinella arctica, holotype, ․ A. Left Gn1. B. Right Gn2. C. Right P3. D. Peraeon and pleon. 
$2^{\text {nd }}$ and $3^{\text {rd }}$ joints setose, $1^{\text {st joint longer than }} 3^{\text {rd }}, 2^{\text {nd }}$ joint 4 times as long as $3^{\text {rd }}$. Inner plate of maxilla 1 much narrower than outer plate, apically with 2 strong setae; outer plate broad, with 10 dentate spines on the blunt apex; palp strong, apically with short, broad teeth. Maxilla 2 with plates apically densely setose. Inner plate shorter, and only half as broad as outer plate. Maxilliped has inner lobe somewhat oval, apically blunt, beset with setae and a few short heavy denticles; outer lobe oval, reaches to the last third of $2^{\text {nd }}$ joint of palp; distal part of inner margin beset with short thick teeth apically ending in spines; palp normal, $2^{\text {nd }}$ joint twice as long as $3^{\text {rd }}$ joint."
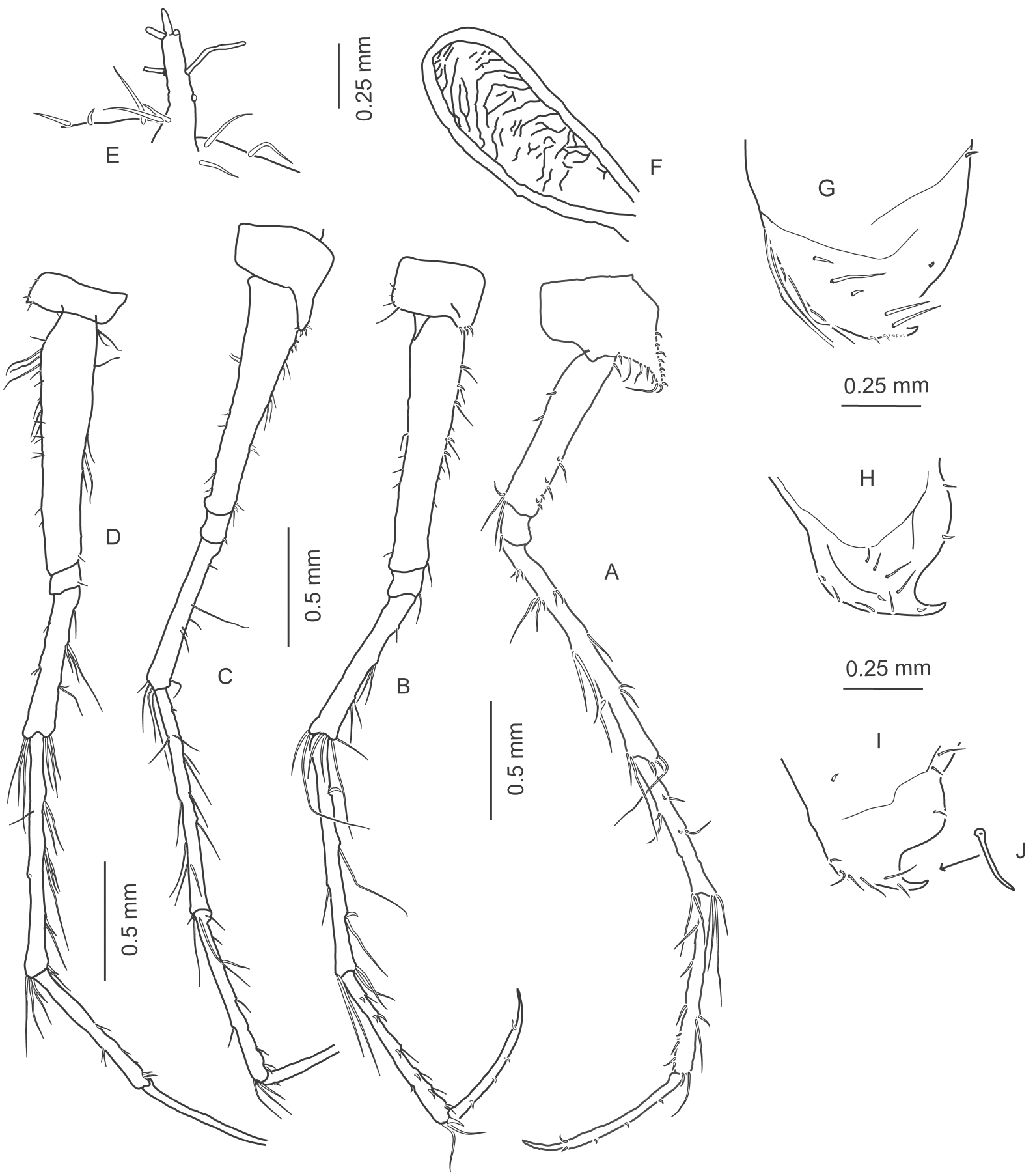

Fig. 4. Lepechinella arctica, holotype,, . A. Right P4. B. Right P6. C. Right P5. D. Right P7. E. Tooth of peraeon segment 6. F. Gill of P5. G. Ep1. H. Ep2. I. Ep3. J. Spine on Ep3. 
Peraeon. Gills smooth with distinct distal capillary pattern; Gnathopods with slender setae on both margins. Gnathopod 1 subchelate; coxal plate 1 asymmetrically bifid, anterior process $2 x$ the posterior process; coxal plate 1 medially tapering; propodus subequal to carpus; propodus $0.5 \mathrm{x}$ basis; posterior margin of carpus with 5 rows of long setae; medial part of propodus with 3 groups of setae; palm of propodus with serrulations; dactyl curved and $0.5 x$ propodus. Gnathopod 2 subchelate and longer than gnathopod 1; coxal plate 2 tapering to an acute tip; carpus longer than merus and propodus; dactyl curved; palm of propodus serrulate. Anterior part of coxal plate 3 acute, posterior part squarely produced; width of coxal plate 3 is $4 \mathrm{x}$ width of basis; peraeopod 3, merus $2 \mathrm{x}$ carpus; merus longer than basis; propodus subequal to carpus and dactyl; dactyl lanceolate. Coxal plate 4 pointed anteriorly, posterior part squarely produced; width of coxal plate 4 is $4 \mathrm{x}$ width of basis; peraeopod 4 , merus is the longest article and $1.3 \mathrm{x}$ basis; basis and propodus subequal in length; dactyl and carpus shorter than propodus; dactyl lanceolate. Coxal plate 5 is anteriorly pointed; peraeopod 5 , carpus longer than merus and propodus; dactyl is broken. Coxal plate 6 rectangular shaped with an anterior bulge; peraeopod 6, merus shorter than carpus and subequal to propodus; basis longer than carpus; dactyl shorter than propodus; dactyl lanceolate. Coxal plate 7 parallogram-shaped and $2 \mathrm{x}$ broader than high; peraeopod 7 , merus shorter than carpus and subequal to propodus; basis with a posterior proximal lobe; the tip of the lanceolate dactyl is broken.

Pleon. Segments 1-3 shorter than peraeon segments 1-7; pleon segments 1-3 with one small and large mid-dorsal tooth each; lateral lobes on pleon; epimeral plate1 larger than plates 2 and 3; posterodistal angle of epimeral plates 1-3 acute and forming a sinus, sinus largest in epimeral plates 2 and 3 ; few setae and some scattered spines on epimeral plates $1-3$.

\section{Remarks}

L. arctica is characterized by few dorsal and lateral setae and spines. Posterior part of coxal plates 3 and 4 are squarely produced and $4 x$ broader than basis. The shape of coxal plate 3 and 4 and relative length of leg articles of peraeopod 3 and 4 are different from $L$. schellenbergi and $L$. norvegica sp. nov. (Table 1). Peraeopod 3 merus / carpus ratio is significantly higher in L. arctica than in the two other species. Schellenberg dissected the mouthparts of specimens from Spitzbergen and described them briefly. However, the mouthparts could not be drawn since we were unable to locate them in the collections. Schellenberg wrote that the postantennal corner of $L$. arctica was acute and mandible palp article 1 longer than article 3 , which is different from $L$. norvegica sp. nov. Antenna 2 peduncle article 5 is $1.5-2 \mathrm{x}$ the length of the penultimate peduncle article in L. schellenbergi and L. norvegica sp. nov. Schellenberg wrote that the two last peduncle articles on the antenna 2 are subequal in length and that the flagellum was broken. However, the exact length of antenna 2 peduncle article 5 is uncertain, because the distal part of peduncle article 5 may also have been lost. Peraeopod 7 carpus of $L$. arctica is 1.6x propodus. Coxal plate 7 has the shape of a parallelogram and the posterior corner of coxal plate 7 is acute. The Peraeopod 7 carpus / propodus ratio is significantly lower in L. schellenbergi and L. norvegica sp. nov. and the posterodistal part of coxal plate 7 is rounded in these two species.

Lepechinella norvegica sp. nov. urn:Isid:zoobank.org:act:F3E97726-1656-45CF-BD00-98A19A172FD0 Figs 5-9

\section{Diagnosis}

Eyes absent. Body heavily covered with spines and setae. Rostrum longer than lateral processes. Mandible palp article 1 subequal to article 3. Molar oval with ragged margins. Maxilliped palp 4-articulate. Posterior legs long and very slender. Coxal plate 4 symmetrically bifid. Posterodistal corner of coxa 7 rounded. Gills smooth. Pleon segments 1-3 each with one small and one large dorsal tooth. Telson deeply cleft. 
JOHANSEN P.-O. \& VADER W., Lepechinella and Lepesubchela gen. nov. from the North Atlantic

\section{Etymology}

norvegica $($ Latin $)=$ Norwegian .

\section{Material examined}

The holotype of Lepechinella norvegica sp. nov. was collected during the Mareano project using RPsledge at station R-578, situated at Teistengrunnen on the Norwegian coast. The sediment at R-578 consisted of sandy mud with gravel. Additional material examined was collected from the Mareano-

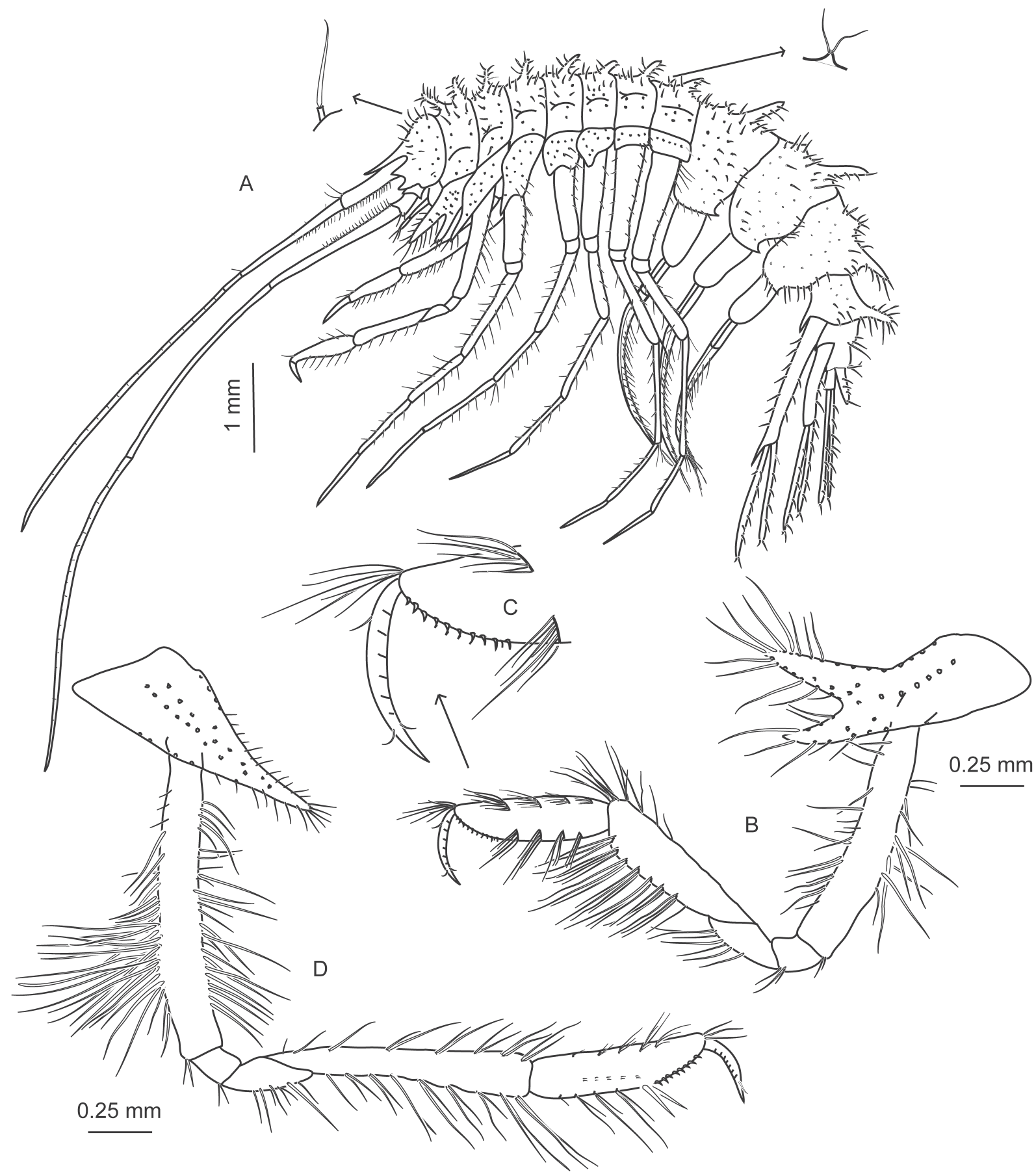

Fig. 5. Lepechinella norvegica sp. nov., holotype, đ. A. Habitus. B. Left Gn1. C. Dactyl and propodus of Gn1. D. Right Gn2. 
station R-11, Tromsøflaket and from station 1136-79, Bleikdypet. The type material of Lepechinella sp. nov. is deposited in the collections of Bergen Zoological Museum and Tromsø Museum in Norway.

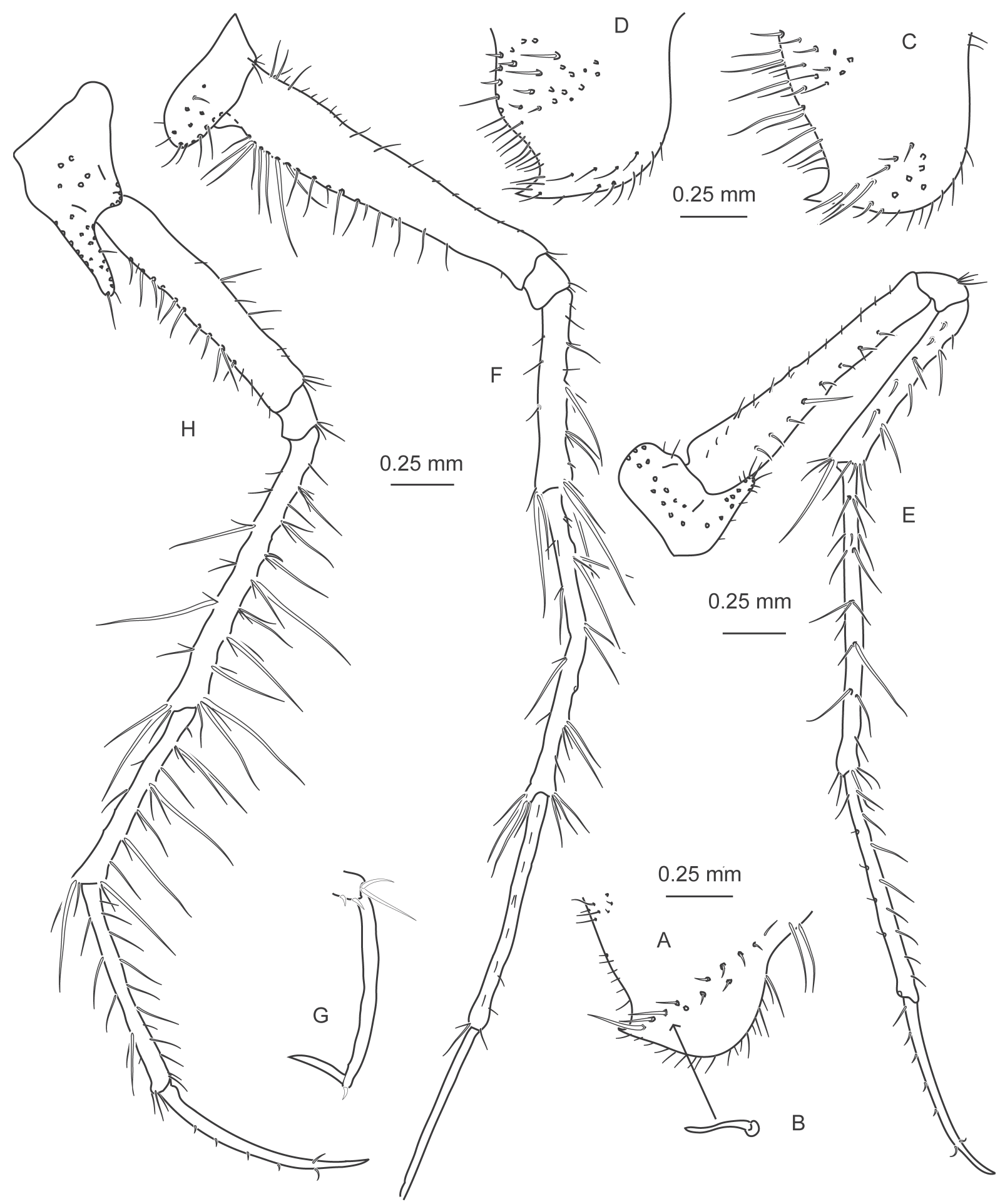

Fig. 6. Lepechinella norvegica sp. nov., holotype, ô. A. Right Ep1. B. Spine on Ep1. C. Right Ep2. D. Right Ep3. E. Left P5. F. Right P7. G. Dactyl of left P7. H. Left P3. 
JOHANSEN P.-O. \& VADER W., Lepechinella and Lepesubchela gen. nov. from the North Atlantic

\title{
Holotype
}

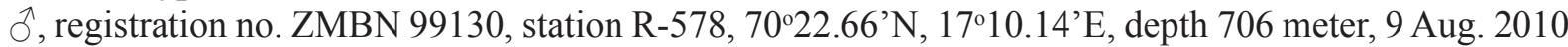

(Figs 5-8).

\author{
Allotype \\ 9, registration no. ZMBN 99131, station R-578, position and date as for holotype (Fig. 9).
}

\section{Additional material}

Ô, registration no. ZMBN 99132, station R-578, position and date as for holotype.

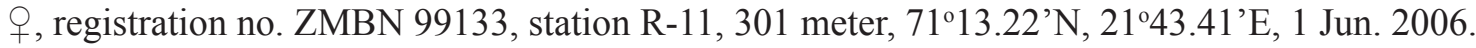

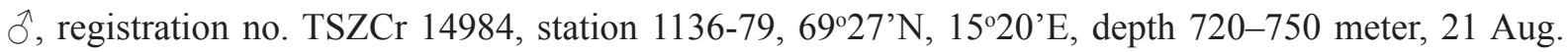
1979.

\section{Description}

\section{Holotype}

Adult male $7 \mathrm{~mm}$.

BoDy. Abundantly covered dorsally and laterally with long setae and spines. Spines, which vary in length, are attached to discs. Coxal plates posteriorly decreasing in height. 2 mid-dorsal teeth on peraeon segment 1 and one on each peraeon segments 2-7. One small mid-dorsal wart with 2 setae prior to the tooth on peraeon segment 7. Pleon segments $1-3$, each with 1 small and 1 large dorsal tooth. Gnathopods $1-2$ shorter than peraeopod 3-7.

HEAD. Rostrum acute and $0.5 \mathrm{x}$ antenna 1 peduncle article 1; rostrum 2x eye lobes; postantennal corner with rounded angle; eyes absent or at least indistinct in alcohol; setae on the head attached to cylindershaped pegs. Row of short setae-groups on posterior margin of antenna 1 peduncle articles 1-2; peduncle article 1 broader than peduncle articles 2-3; peduncle article 2 medially tapering and $2 x$ peduncle article 1 ; peduncle article 3 is $1 / 3$ of peduncle article 1; flagellum with at least 26 articles (the tip is broken); flagellum 1.4x peduncle articles 1-3 combined; accessory flagellum is 1-articulate with two apical setae. Antenna 2 longer than antenna 1; antenna 2 peduncle articles 4-5 anterior margin with row of setae groups distally decreasing in length; peduncle articles 1,2 and 3 broader than peduncle articles 4 and 5 ; peduncle article 4 distally tapering; peduncle article 5 is $2 x$ peduncle article 4 ; flagellum longer than peduncle article 5; flagellum 33-articulate.

MoutHPaRTs. Upper lip oval lobes and medially constricted; lower lip bilobate; inner lobe extending to $1 / 2$ of the outer lobe. Mandible, incisor and lacinia mobilis of subequal length, both with denticles; molar is elliptic, saucer-shaped with ragged margins; 6-7 accessory spines; mandible palp article 1 and 3 subequal; mandible article 2 slightly curved with 12 long setae; mandible article 2 is $4 \mathrm{x}$ article 3 , mandible article 3 with 4 lateral and 4 long apical setae. Maxilla 1, inner plate narrow with 2 apical plumose setae; outer plate tapering distally, with 10 apical serrate spine teeth; palp 2-articulate obliquely truncated; palp with 6-7 blunt spines and one longer apical spine. Maxilla 2, inner plate shorter and narrower than outer plate; outer plate with about 25 distal long setae; inner plate with 1 strong plumose setae in addition to apical setae; inner margin of inner plate lined with setae. Maxilliped, outer plate $2 \mathrm{x}$ inner plate; inner plate slender with 3 blunt apical teeth and setae along the inner margin; outer plate armed with 14 broad spine teeth of decreasing length on distal and medial margin; outer plate reaches article 3 of palp; palp 4-articulate where the second article is subequal to the two last articles combined.

Peraeon. Coxal plate 1, 3 and 4 biacuminate, coxae partly covered with setae and spines attached on disc-shaped pegs. Gills, shape oval and smooth. Gnathopod 1 subchelate; coxal plate 1 asymmetrically 
bifid with long setae along distal margins; anterior coxal plate 1 process $1.4 \mathrm{x}$ posterior process; propodus shorter than carpus and distally tapering; posterior margin of carpus with 7 groups of long setae; dactyl curved with 6 notches; dactyl $0.5 x$ propodus; both margins of propodus with 4 groups of setae; palm of propodus serrulate. Gnathopod 2 longer than gnathopod 1. Coxal plate 2 tapering to an acute tip; gnathopod 2 , merus $1 / 3$ of carpus; carpus $1.4 x$ propodus; dactyl curved with 7 notches; palm of propodus serrulate. Coxal plate 3 asymmetrical, anterior part pointed, posterior part with a small hump; peraeopod 3 , merus 1.6x carpus; propodus and dactyl subequal; dactyl lanceolate. Coxal plate 4 symmetrically

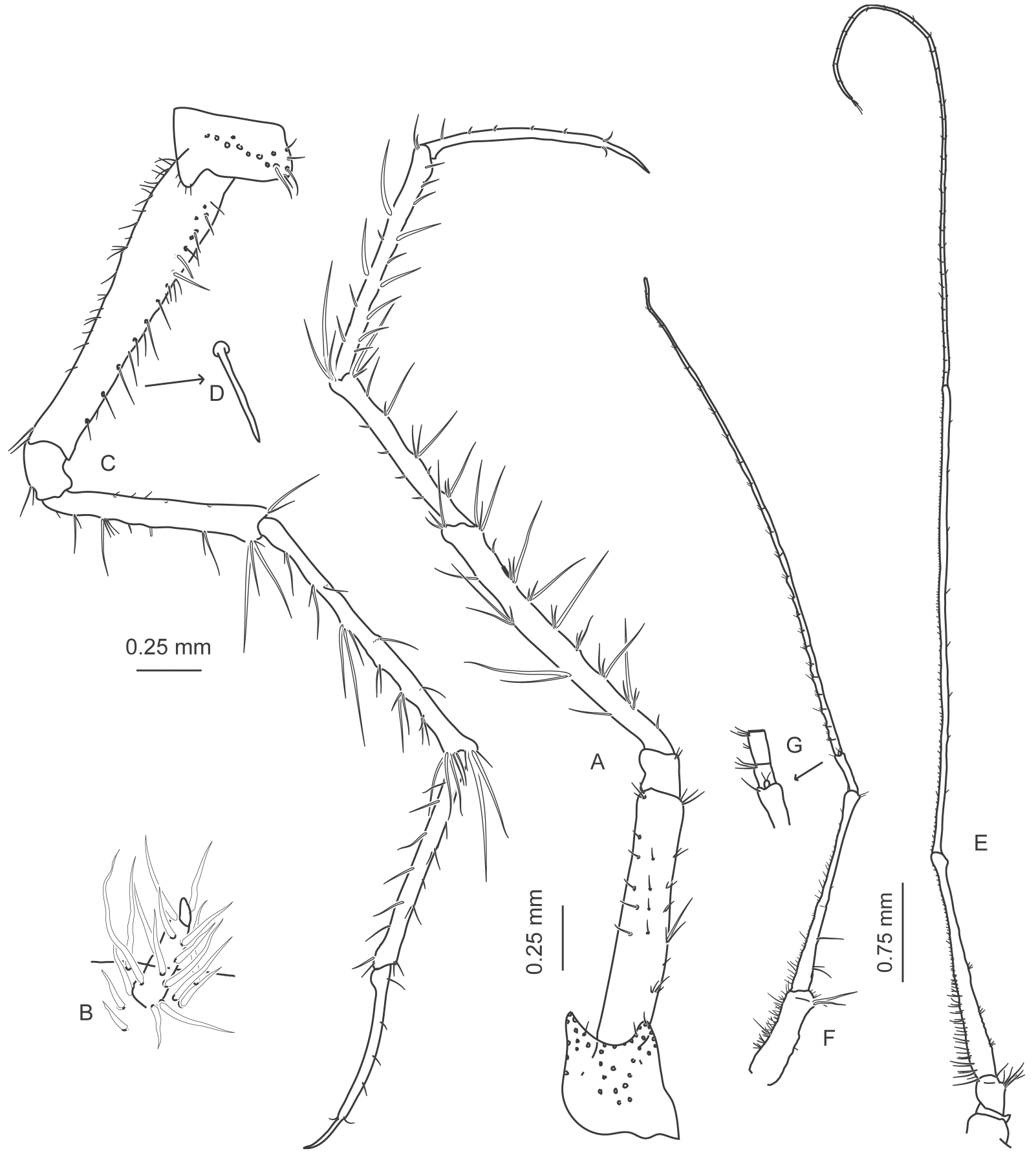

Fig. 7. Lepechinella norvegica sp. nov., holotype, $\partial$. A. Right P4. B. Tooth of peraeon segment 4. C. Left P6. D. Spine on basis of P6. E. Male A2. F. Male A1. G. Accessory flagellum on A1. 
JOHANSEN P.-O. \& VADER W., Lepechinella and Lepesubchela gen. nov. from the North Atlantic

bifid; peraeopod 4, merus 1.6x carpus; carpus $0.7 \mathrm{x}$ propodus and dactyl; short spines and setae on coxal plate 4 and basis. Coxal plate 5 anteriorly acute, posterior part rounded; peraeopod 5 , merus $0.6 \mathrm{x}$ carpus; carpus $1.3 \mathrm{x}$ propodus; dactyl lanceolate; dactyl shorter than propodus. Coxal plate 6 anteriorly bluntly pointed; peraeopod 6 , merus subequal to propodus; merus $0.7 \mathrm{x}$ carpus; small spines and setae on coxal plate 6 and basis; dactyl shorter than propodus; dactyl lanceolate. Coxal plate 7 anterior part acute and posterior rounded; coxal plate 7 is $2 \mathrm{x}$ broader than high; peraeopod 7 , merus $0.6 \mathrm{x}$ carpus; carpus $1.3 \mathrm{x}$ propodus.

Pleon. Segments 1, 2 and 3 each with one large and one small dorsally situated tooth. Posterodistal angle of epimeral plates 1-3 acute, forming a small sinus; epimeral plate 3 sinus largest; setae along margins and 2 arrays of spines on epimeral plates 1-3. Urosome segment 1 subequal to 2 and 3 combined; urosome segment 1 with 1 mid-dorsal tooth; urosome segments 2 and 3 fused. Uropod 1 peduncle has two distal spines and rows of spines along the margins; peduncle longer than both rami; inner ramus $0.9 x$ outer. Uropod 2 peduncle shorter than inner ramus and subequal to outer; outer ramus $0.8 \mathrm{x}$ of inner ramus. Uropod 3 peduncle about $1 / 5$ of the rami; longer ramus $1.1 \mathrm{x}$ shorter; rami densely covered with long setae. Telson parts are gaping, cleft to $80 \%$ of total length; length of apical setae subequal to telson; four setae along the margins of telson, four spines on the dorsal part of the last urosome segment.

\begin{abstract}
Allotype
Adult female $7 \mathrm{~mm}$.

Antenna 1 peduncle article 1 is $1.5 x$ article 3 ; scattered long setae along margins of peduncle article 2 ; peduncle article 2 is $2.5 \mathrm{x}$ peduncle article 1 ; peduncle article 1 broader than peduncle articles $2-3$; flagellum 24-articulate; flagellum $1.5 x$ peduncle articles $1-3$ combined; accessory flagellum is 1 -articulate with two apical setae. Antenna 2 length subequal to antenna 1; antenna 2 peduncle articles 3-5 margins with groups of setae decreasing in size distally; peduncle articles $2-3$ broader than peduncle articles $4-5$; peduncle articles 5 is $1.5 x$ peduncle article 4 ; flagellum subequal to peduncle article 5 ; flagellum 18-articulate. Gills oval and smooth. Uropod 3, peduncle 1/6 of longer ramus; shorter ramus $0.9 \mathrm{x}$ longer, rami with long setae along the margins; posteriodistal angle of epimeral plates 1-3 acute, forming a sinus; sinus largest in epimeral plates 2 and 3; setae and spines on epimeral plates 1,2 and 3.
\end{abstract}

\title{
Variation
}

The rostrum is about $30 \%$ of the length of antenna 1 peduncle article 1 in $2 \mathrm{~mm}$ long specimens while it is about $50 \%$ in $7 \mathrm{~mm}$ long specimens. The dorsal teeth of coxal plate 1 are about $50 \%$ of the body height of peraeon segment 1 in 6-7 mm long specimens, but only $20 \%$ in $2 \mathrm{~mm}$ long specimens. Large specimens have one small dorsal wart armed with two setae prior to the large posterior tooth of peraeon segment 7. Males have large teeth that are pointing backwards, while females have more slender and upright teeth on pleon. Female antenna 1 and 2 peduncle margins have scattered long setae, while males have dense rows of small setae. Antenna 2 is longer than antenna 1 in males, while they are subequal in females and antenna 2 peduncle article 5 is $2 x$ the penultimate peduncle article in males, while it is $1.5 \mathrm{x}$ in females. Posterodistal angle of epimeral plate 3 is situated more in centre in females than males, which results in a larger sinus in females. The setae on the rami of uropod 3 seem to be denser in males than in females. Sexual dimorphism has also been observed in dorsal armature, posterodistal shape of epimeral plates and setal armature of antennal peduncles of L. helgi, L. grimi and L. skarphedini (Thurston 1980a).

\section{Remarks}

L. norvegica sp. nov. from Northern Norway is characterized by a dense cover of long setae and spines. Spines with the longer setae are usually situated dorsally while spines on disc-shaped pegs are mainly situated laterally on the body, on the coxae and on the basis of the posterior legs. However, a lot of 
the spines were probably broken, leaving only the disc to which they were attached. Setae attached to cylinder-shaped pegs were observed on the head. The postantennal corner of L. norvegica sp. nov. is rounded while $L$. arctica has an acute postantennal corner according to Schellenberg (Table 1). Mandible palp article 1 and 3 of $L$. norvegica sp. nov. are subequal, while article 3 is larger in $L$. schellenbergi and $L$. arctica. The molar is elliptic with small marginal ribs in $L$. norvegica sp. nov. and has a certain similarity to the molar of Lepechinelloides kari Thurston, 1980 and Lepechinella turpis J.L. Barnard, 1967. The width of maxilla 2 inner plate is about $1 / 3$ of the outer in $L$. norvegica sp. nov., while it is about $1 / 2$ in $L$. schellenbergi and L. arctica and $2 / 3$ in L. victoriae sp. nov. L. norvegica sp. nov. has a symmetrical

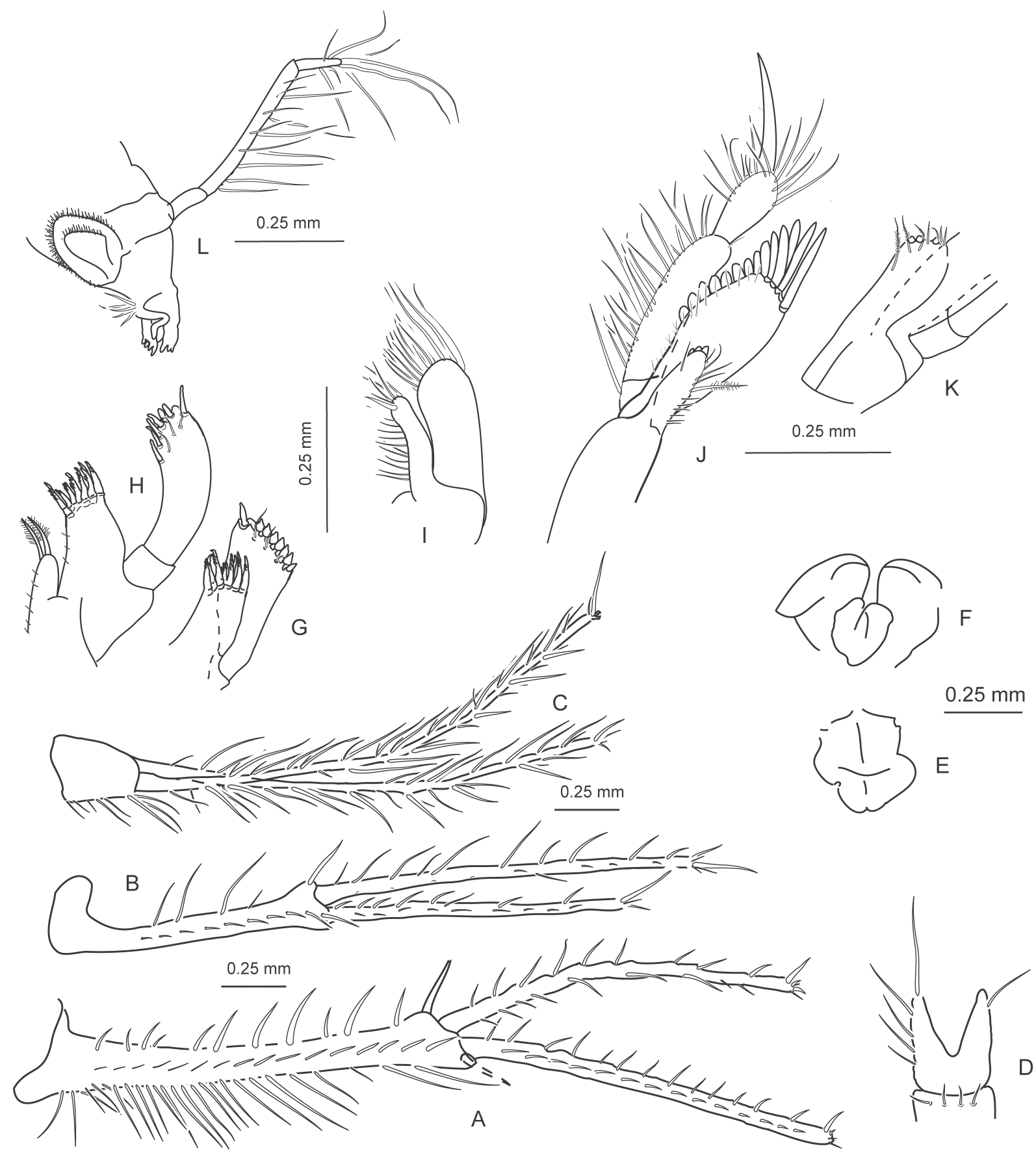

Fig. 8. Lepechinella norvegica sp. nov., holotype, đ̊. A. Left U1. B. Left U2. C. U3. D. Telson. E. Upper lip. F. Lower lip. G-H. Left and right Mx1. I. Right Mx2. J-K. Left and right Mxp. L. Left mandible. 
JOHANSEN P.-O. \& VADER W., Lepechinella and Lepesubchela gen. nov. from the North Atlantic

bilobate coxal plate 4 . Coxal plates 3 and 4 are $2 x$ wider than basis of respective legs and thus the legs seems stouter than in the case of $L$. schellenbergi and $L$. arctica. Peraeopod 3 merus of $L$. norvegica sp. nov. is 1.6x carpus and merus subequal to basis. The merus/carpus ratio is higher in L. arctica and lower in L. schellenbergi. The inner edges of gnathopod 1-2 dactyls have notches resembling dactyls of many Liljeborgia species. The position and number of setae on the telson are different in L. norvegica sp. nov. and $L$. schellenbergi. The telson is more deeply cleft in $L$. norvegica sp. nov.(about $80 \%$ ) than

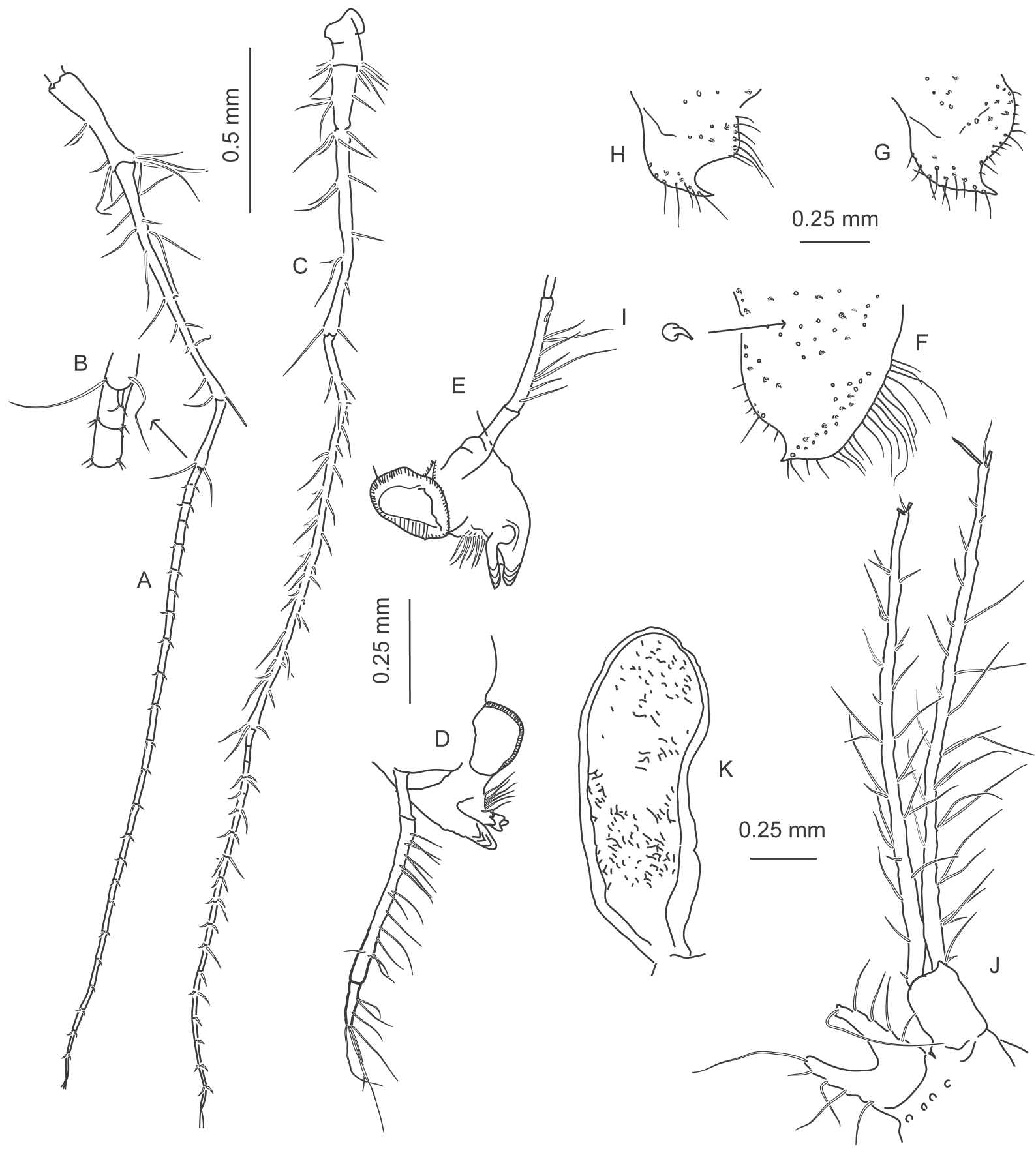

Fig. 9. Lepechinella norvegica sp. nov., allotype, +. A. A1. B. Accessory flagellum of A1. C. Female A2. D-E. Right and left mandible. F. Right Ep1. G. Left Ep2. H. Left Ep3. I. Spine on Ep 1. J. Telson and left U3. K. Gill of P3. 
L. schellenbergi (about $50 \%$ ). Telson of L. grimi and L. skarphedini is about $60-65 \%$ cleft, while it is about $40 \%$ in L. helgi and L.victoriae sp. nov.

Lepechinella schellenbergi Stephensen, 1944

Figs 10-12

Lepechinella schellenbergi Stephensen, 1944: 18-20, fig 11.

Lepechinella arctica - Barnard 1973: 10. — Barnard \& Karaman 1991: 268-270.

\section{Material examined}

About 13 specimens of Lepechinella were collected off the west coast of Greenland during the Ingolf Expedition (Stephensen 1944). The specimens were sampled from station 32 at 599 meters depth, 11 Jul. 1895 and station 35 at 682 meters depth 18 Jul. 1895 . The position of station 32 was at $66^{\circ} 35^{\prime} \mathrm{N}$, $56^{\circ} 38^{\prime} \mathrm{W}$ and station 35 was at $65^{\circ} 16^{\prime} \mathrm{N}, 55^{\circ} 05^{\prime} \mathrm{W}$. The in situ temperatures at the collection sites were $3.6-3.9^{\circ} \mathrm{C}$.

The type material of Lepechinella from Greenland is deposited in the collections of Zoological Museum in Copenhagen, Denmark. The examined material was prepared on microscope slides from station 35, from one entire female in addition to the front part of one male and female that probably had been cut during sampling.

\section{Lectotype}

+, Ingolf st. 35, on slide (reg.no. ZMUC-CRU-4468) (Figs 10-11).

\section{Paralectotypes}

o, Ingolf st. 35, on slide (reg.no. ZMUC-CRU-4469) (Fig. 12).

ㅇ, Ingolf st. 35, on slide (reg.no. ZMUC-CRU-4470) (Fig. 12).

3 paralectotypes, Ingolf st. 32 (reg.no. ZMUC-CRU-8019).

8-9 paralectotypes, Ingolf st. 35 (reg.no. ZMUC-CRU-8020).

Stephensen (1938) translated Schellenberg's description of Dorbanella sp. as Lepechinella sp. He was then probably unaware that Schellenberg (1926) in a footnote had changed the name from Dorbanella sp. to Lepechinella artica. When describing the specimens from Greenland, Stephensen (1944) assumed that this was the same species as Schellenberg had recorded from Spitzbergen and named it Lepechinella schellenbergi nom. nov. The specimens from Greenland were later assumed to be Lepechinella arctica (Barnard 1973; Barnard \& Karaman 1991).

\section{Redescription}

Lectotype

Female $6 \mathrm{~mm}$.

BoDy. Covered mainly dorsally and laterally with setae and spines. The spines, which varied in length, are attached to disc-shaped pegs and varied in size. Peraeon segment 1 with two dorsal teeth, peraeon segments 2-7 each with one large mid-dorsal tooth. Urosome segment 1 with 1 dorsal tooth.

HEAD. Larger than the first body segment; two anteriorly pointing lateral eye lobes; rostrum longer than the eye lobes; eyes absent or at least indistinct in alcohol; anterior postantennal corner with rounded 
JOHANSEN P.-O. \& VADER W., Lepechinella and Lepesubchela gen. nov. from the North Atlantic

angle. Rostrum, about half the length of antenna 1 peduncle article 1 . Antenna 1 peduncle article 1 broader than article 2 and 3 ; article 2 is $2 x$ article 1 and distally tapering; peduncle article 2 is $5 \mathrm{x}$ the length of article 3; flagellum 20-articulate; flagellum $1.5 x$ longer than peduncle articles 1-3 combined; accessory flagellum 1-articulate with two apical setae. Antenna 2 peduncle articles $1-3$ broader than article 4-5; peduncle article 4 is $3 x$ peduncle articles 1-3 combined; peduncle article 4 tapering distally; distal part of peduncle article 5 is lost.

MouthPARTs. Mandible incisor stronger than lacinia mobilis, both armed with denticles, molar surface with transverse ribs, 5-6 accessory spines. Maxilla 1, inner plate distally tapering with two apical setae;

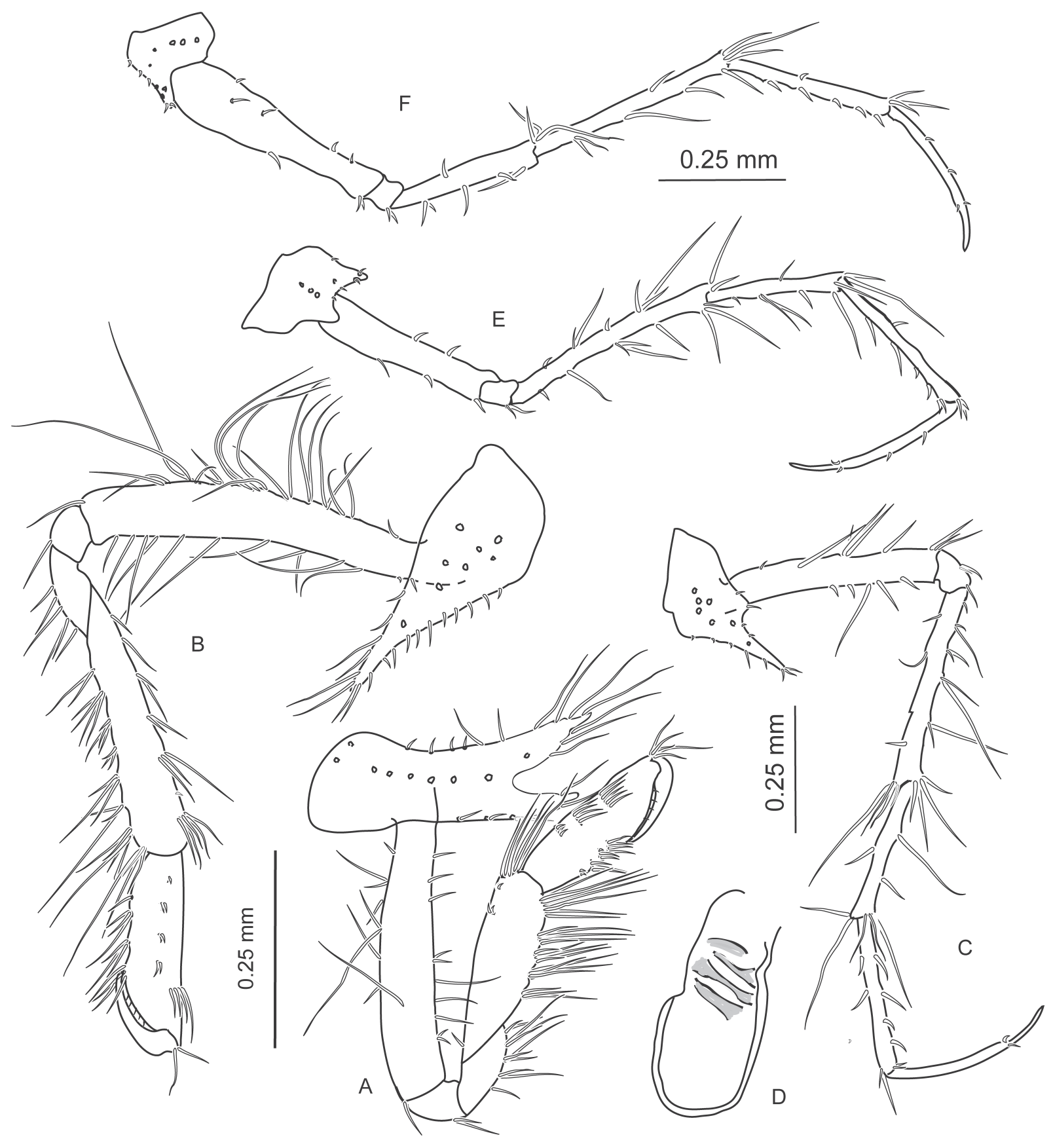

Fig. 10. Lepechinella schellenbergi Stephensen, 1944, lectotype, ㅇ. A. Right Gn1. B. Right Gn2. C. Left P3. D. Gill of P5. E. Right P4. F. Left P5. 
outer plate broad with 7 serrate spine teeth; palp distally expanded and obliquely truncated, with 6 blunt spines and one apical long spine. Maxilla 2, inner plate shorter and narrower than outer plate; outer plate with 13 distal setae; inner plate with 5 apical setae. Maxilliped, inner plate reaching to $1 / 2$ of outer plate, apically 3 blunt spines and a few setae; outer plate with 11 broad spine teeth of varying length; palp 4-articulate; outer plate reaches to end of palp article 3.

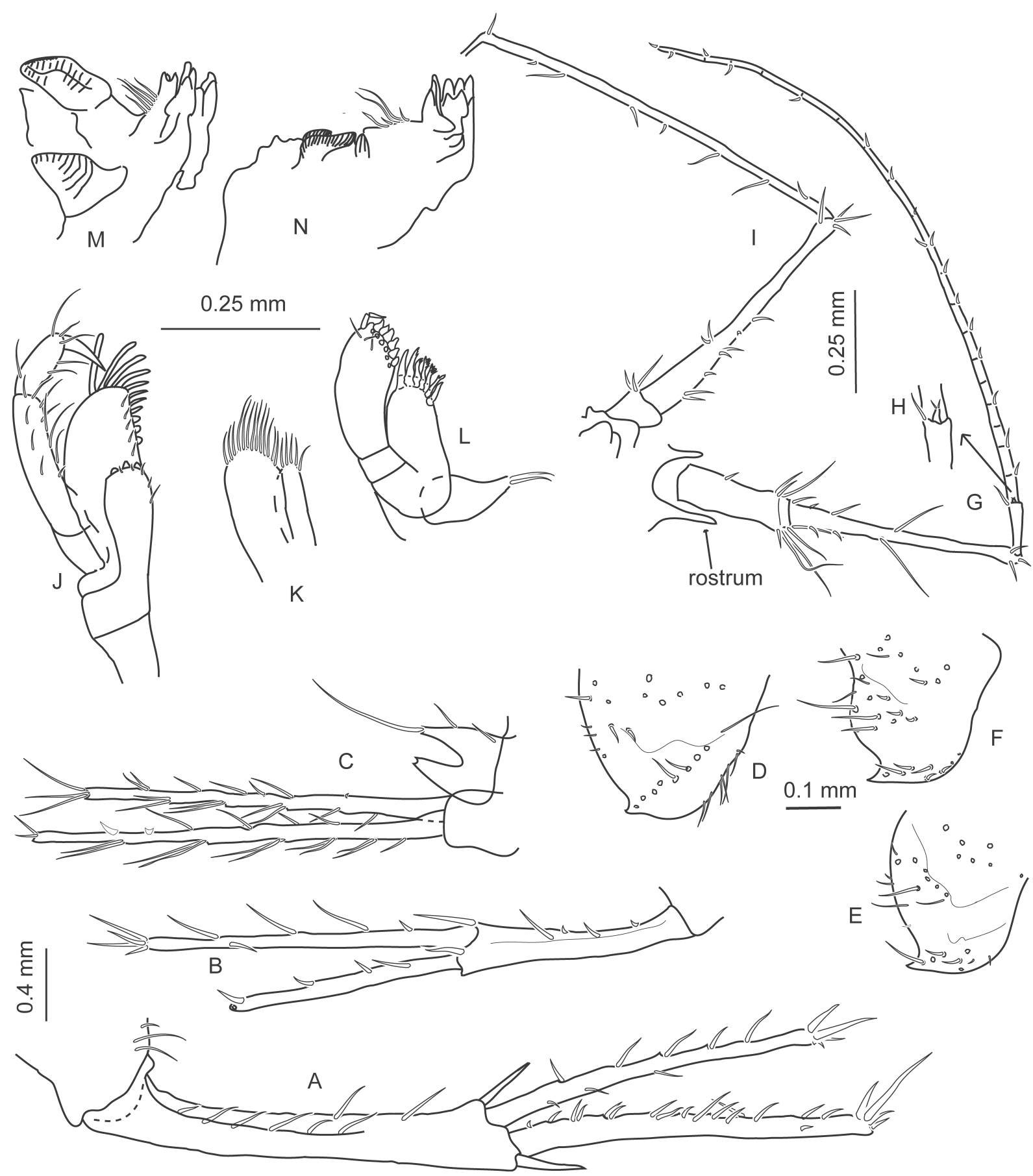

Fig. 11. Lepechinella schellenbergi Stephensen, 1944, lectotype, ․ . A. Left U1. B. Right U2. C. Right U3 and telson. D. Right Ep1. E. Right Ep2. F. Right Ep3. G. Female A1. H. Accessory flagellum. I. Female A2. J. Left Mxp. K. Left Mx2. L. Left Mx1. M-N. Left and right mandible. 
JOHANSEN P.-O. \& VADER W., Lepechinella and Lepesubchela gen. nov. from the North Atlantic

Peraeon. Proximal part of gills obliquely pleated. Gnathopod 1, subchelate; coxal plate 1 asymmetrically bifid; propodus distally tapering and slightly shorter than carpus; 5 groups of long setae on posterior part of carpus; dactyl curved; dactyl $1 / 2$ the length of propodus; 3-4 groups of setae on anterior and posterior margins of propodus; palm of propodus serrulate. Gnathopod 2 longer and more slender than gnathopod 1; coxal plate 2 tapering to an acute tip; gnathopod 2, basis $1.2 \mathrm{x}$ longer than carpus; $6-8$ groups of setae along the margins of carpus; carpus longer than propodus; palm of propodus serrulate; dactyl curved. Peraeopod 3 longer than gnathopod 1 and 2; coxal plate 3 asymmetrically bifid and anterior part acute; merus longer than carpus; merus subequal to basis; carpus subequal to propodus and dactyl;

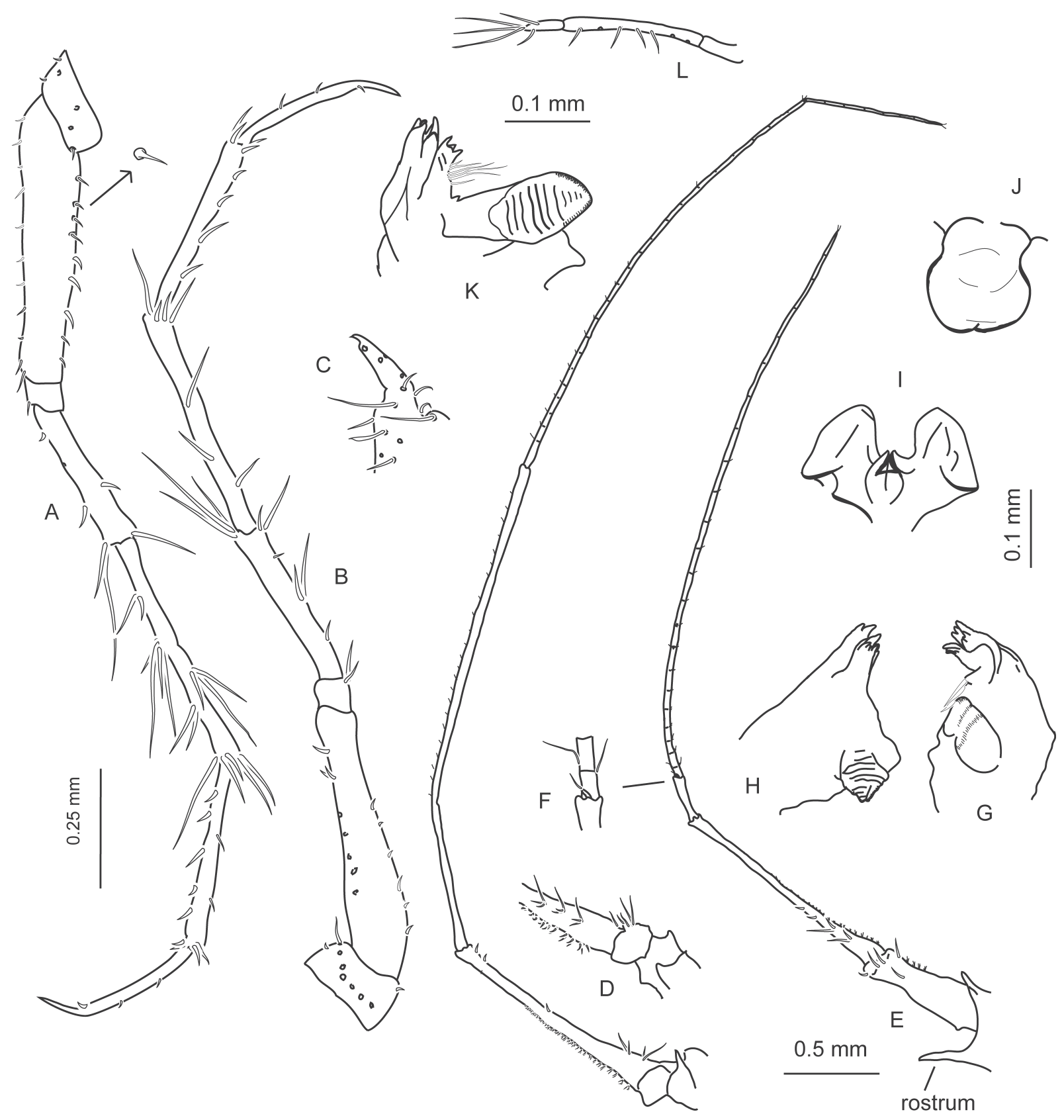

Fig. 12. Lepechinella schellenbergi Stephensen, 1944. - A-C. Lectotype, 9 . A. Left P7, 1 spine on basis is enlarged. B. Left P6. C. Tooth of peraeon segment 6. - D-J. Paralectotype 1, ठ̂. D. Left and right male A2. E-F. Male A1 with accessory flagellum. G-H. Right and left mandible. I. Lower lip. J. Upper lip. - K-L. Paralectotype 2,, , mandible and mandible palp. 
dactyl lanceolate. Coxal plate 4 asymmetrically bifid; proximal posterior part of coxal plate 4 produced; peraeopod 4, merus 1.7x longer than carpus; dactyl subequal to propodus; merus $1.3 \mathrm{x}$ longer than basis. Coxal plate 5 anterior part acute; peraeopod 5, carpus 1.4x merus; carpus shorter than basis; carpus longer than propodus; dactyl lanceolate and subequal to propodus. Coxal plate 6 twice as broad as high; peraeopod 6 , carpus $1.3 \mathrm{x}$ longer than merus and propodus; basis $1.2 \mathrm{x}$ longer than carpus; dactyl shorter than propodus; dactyl lanceolate. Coxal plate 7 is $2.8 \mathrm{x}$ as broad as long; posterodistal part of coxal plate 7 rounded; peraeopod 7 , basis $1.2 x$ longer than carpus; carpus $1.7 x$ longer than merus; propodus longer than dactyl, dactyl lanceolate.

Pleon. Segments 1-3 each with one large and one small mid-dorsal process. Posterior angle of epimeral plates 1-3 acute forming a sinus; sinus largest in epimeral plate 3; setae along margin of epimeral plate 1 ; spines distributed in 2-3 arrays on epimeral plates 1-3. Urosome segment 1 with one tooth; length of urosome segment 1 subequal to 2 and 3 combined; urosome segments $2-3$ fused. Uropod 1 peduncle with 2 distal large spines and several smaller marginal ones; peduncle longer than rami; outer ramus $1.1 \mathrm{x}$ inner ramus. Uropod 2 peduncle subequal to outer ramus; outer ramus $0.7 \mathrm{x}$ inner. Uropod 3 peduncle $1 / 5$ of rami; shorter ramus $0.9 \mathrm{x}$ longer. Telson cleft to $50 \%$ of total length and widely gaping; apical setae longer than telson; 2 setae along each lateral margin of telson.

\section{Paralectotype 1}

Female, head + peraeon segments $1-4=2 \mathrm{~mm}$.

Mandible, incisor longer than lacinia mobilis both with denticles; molar with transverse ribs; 5-6 accessory spines; mandible palp article 1 is $1.2 \mathrm{x}$ article 3 ; mandible palp article 2 is $4 \mathrm{x}$ article 3 .

\section{Paralectotype 2}

Male, head + peraeon segments $1-5=2 \mathrm{~mm}$.

Mandible, incisor and lacinia mobilis with denticles; molar with transverse ribs; 3-4 accessory spines; upper lip rounded lobes, tapering medially; lower lip bilobate, inner lobes reaching $1 / 2$ of outer lobes. Antenna 1, margins of peduncle articles 1-2 with dense row of short setae and a few long setae; peduncle article 1 broader than article 2 and 3; peduncle article 2 is $2 x$ article 1 ; peduncle article 2 tapering medially; peduncle article 3 is $1 / 5$ of article 2; flagellum 23-articulate; flagellum longer than peduncle articles 1-3 combined; accessory flagellum 1-articulate with one apical setae. Antenna 2, peduncle article 4 margins with dense row of small setae, peduncle articles 1-3 broader than article 4-5; article 4 tapering distally; peduncle article 5 is $2.2 \mathrm{x}$ article 4 ; peduncle article 5 shorter than flagellum; flagellum 31-articulate.

\section{Variation}

Rostrum varies in length, from 40-60\% of antenna 1 peduncle article 1 in 5-6 $\mathrm{mm}$ long specimens, to about $35 \%$ in $4 \mathrm{~mm}$ long specimen. The dorsal teeth on peraeon segment 1 are $35-45 \%$ of the body height in 5-6 mm long specimens. Large specimens have one small dorsal wart with two setae, prior to the large posterior tooth of peraeon segment 7 . The teeth on the pleon are stronger in males than in females. The margin of female antennal peduncle has scattered long setae, while that of males has a dense row of small setae. The female epimeral plate 3 sinus is smaller in L. schellenbergi than in L. arctica and L. norvegica sp. nov. Since the shape of epimeral sinus in Lepechinella seems to vary both between gender and species, this character is probably not applicable to distinguish between species.

\section{Remarks}

The dorsal armature of $L$. schellenbergi is not as heavy as in L. norvegica sp. nov. Stephensen did not dissect the mouthparts of $L$. schellenbergi from Greenland. The microscope slides of the specimens from 
JOHANSEN P.-O. \& VADER W., Lepechinella and Lepesubchela gen. nov. from the North Atlantic

the same Greenland stations show that the length of mandible palp and shape of mandible molar are different from $L$. norvegica sp. nov. The molar of $L$. schellenbergi resembles the descriptions of $L$. helgi, L. skarphedini and L. grimi. The coxae shape and relative size of peraeopod 3 and 4 also separate L. arctica, L. schellenbergi and L. norvegica sp. nov. L. schellenbergi has a triangularly produced posterior proximal part of coxal plates 3 and 4, and width of coxae is $3 x$ the width of basis (Table 1). According to Stephensen (1944) the anterior postantennal corner is acute, but on the examined specimens the angle seems rounded. The drawing of antenna 1 and 2 made by Stephensen (op. cit.) is probably from a male because of the dense short setae groups along the antennal peduncle margins, while the drawing of gnathopod 2 is from a female because it includes an oostegite. The tip of uropod 2 is broken in Stephensen's figure. However, the microscope slides show that the length of outer ramus of uropod 2 is $0.7 \mathrm{x}$ inner, in $L$. schellenbergi as in $L$. victoriae sp. nov. and $L$. manco, while it is $0.8 \mathrm{x}$ in $L$. norvegica sp. nov. and subequal in L. helgi.

Lepechinella victoriae sp. nov. urn:1sid:zoobank.org:act:AD61D708-1965-42F1-9352-FC42969F9EC7

Figs 13-16

\section{Diagnosis}

Eyes absent. Body sparsely covered with spines and setae. Lateral processes of head acute, as long as rostrum. Inner lobes of lower lip well developed. Mandible palp article 1 half the length of article 3. Maxilliped palp 4-articulate. Posterior legs long and very slender. Anterodistal part of coxae 3-5 strongly produced. Posterodistal corner of coxa 7 acute. Gills proximally pleated. Posterior part of pleon segments 1-4 each with one dorsal tooth.

\section{Etymology}

The species is named after POJ's first grandchild.

\section{Material examined}

Two specimens of Lepechinella victoriae sp. nov. were collected at station 83.06.5.1, in the North East Atlantic, south of Iceland. The in situ temperature was measured to $2.7^{\circ} \mathrm{C}$. The type material of Lepechinella victoriae sp. nov. is deposited in the collections of Zoological Museum in Bergen.

\section{Holotype}

Adult female, registration no. ZMBN 99134, $5.5 \mathrm{~mm}$, station 83.06.5.1, 61'38. ${ }^{`} \mathrm{~N}, 16^{\circ} 27.7^{\prime} \mathrm{W}, 2355$ meter depth, 5 Jun. 1983.

\section{Paratype}

Female, registration no. ZMBN 99135, $4.5 \mathrm{~mm}$, date and position as for holotype.

\section{Description}

Holotype

Female, $5.5 \mathrm{~mm}$.

BoDy. Sparsely covered with short setae, mainly situated mid-dorsally. Peraeon segment 1 with 2 teeth, peraeon segments 2-7 each with one mid-dorsal tooth. Coxal plates short, decreasing in length posteriorly.

HEAD. Subequal to peraeon segments 1-2; rostrum acute, horizontal, length $0.5 x$ antenna 1 peduncle article 1; lateral processes acute, as long as rostrum; eyes absent or at least indistinct in alcohol. Antenna 1, peduncle article 1 thicker than articles 2 and 3 and $0.5 x$ length of peduncle article 2; peduncle article 3 
is $0.4 \mathrm{x}$ article 1; scattered long setae on peduncle article 2 and distally on peduncle articles 1 and 3; flagellum twice as long as peduncle articles 1-3 combined; flagellum 30-articulate. Accessory flagellum short, consisting of one article with two long apical setae. Antenna 2 is slightly longer than antenna 1. Antenna 2, peduncle articles $1-3$ combined $1 / 3$ of article 4 ; peduncle article 4 is $0.6 x$ article 5 ; flagellum longer than peduncle article 5; flagellum 20-articulate.

MouthPARTS. Upper lip oval; lower lip inner lobes large, extending to $3 / 4$ of outer lobes; mandible incisor and lacinia mobilis of subequal length, gaping at $45^{\circ}$ angle; 6-7 accessory spines; molar round, with ragged margins; mandible palp article 1 is $0.5 \mathrm{x}$ article 3 ; mandible article 2 is $3 \mathrm{x}$ article 3 ; mandible

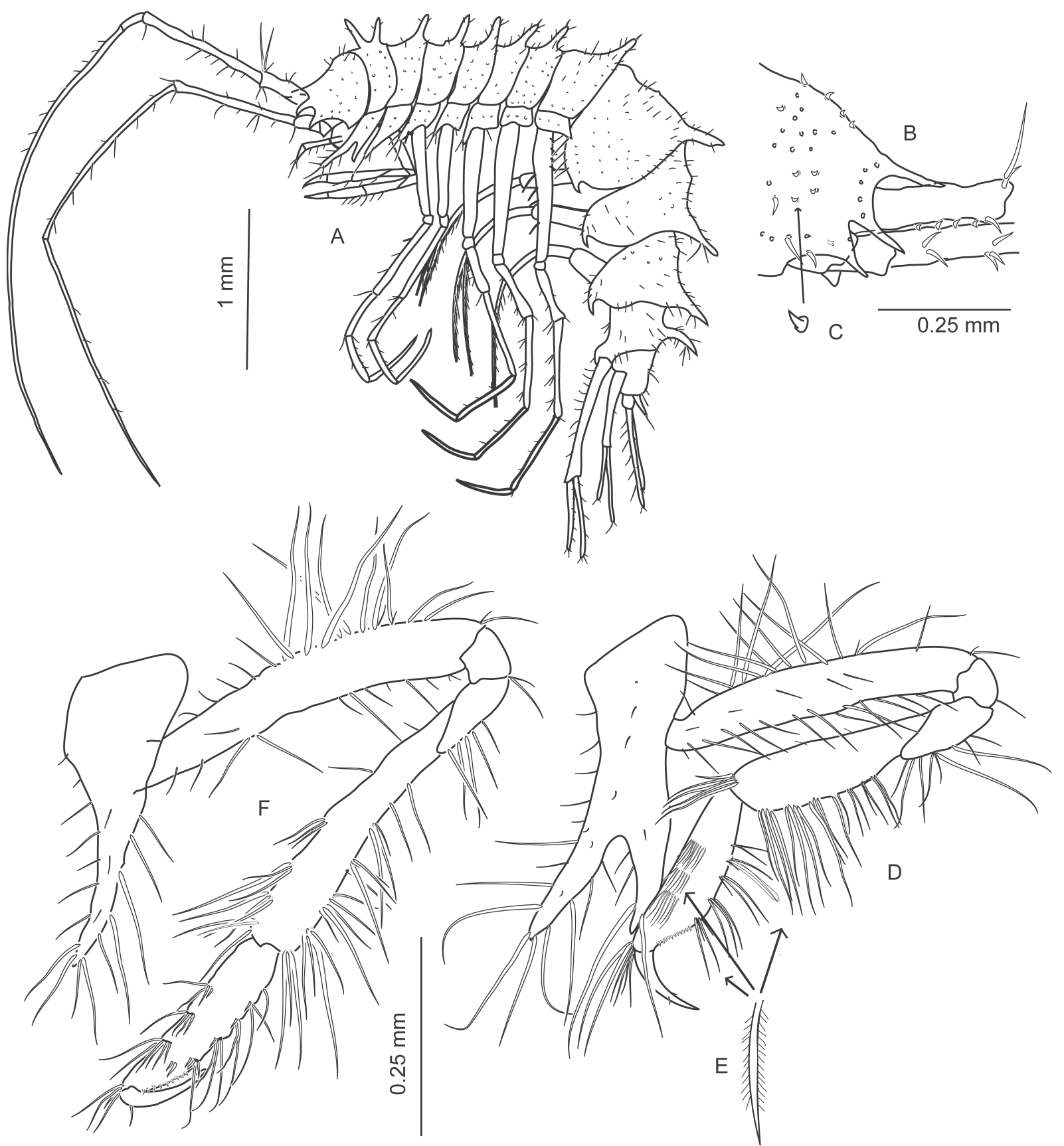

Fig. 13. Lepechinella victoriae sp. nov., holotype, ․ . A. Habitus. B. Head. C. Spine on head. D. Left Gn1. E. Plumose setae. F. Left Gn2. 
JOHANSEN P.-O. \& VADER W., Lepechinella and Lepesubchela gen. nov. from the North Atlantic

article 2 and 3 with 10 and 6 setae, respectively. Maxilla 1, inner plate stout, $0.5 x$ outer plate, with 2 apical plumose setae; outer plate with $8-10$ strong spine teeth; palp 2-articulate, article 2 distally expanded, with 7 short and 1 long distal spines. Maxilla 2, inner plate broad and slightly shorter than outer plate, with short marginal and long apical setae; outer plate with 16 long apical setae. Maxilliped, inner plate half the length and width of outer plate; outer plate with 11-12 long spine teeth on inner margin and apically, increasing in length distally; palp 4-articulate; outer plate reaches article 3 of palp; article 2 slender and by far the longest, with long setae on inner margin; long setae on article 1-3.

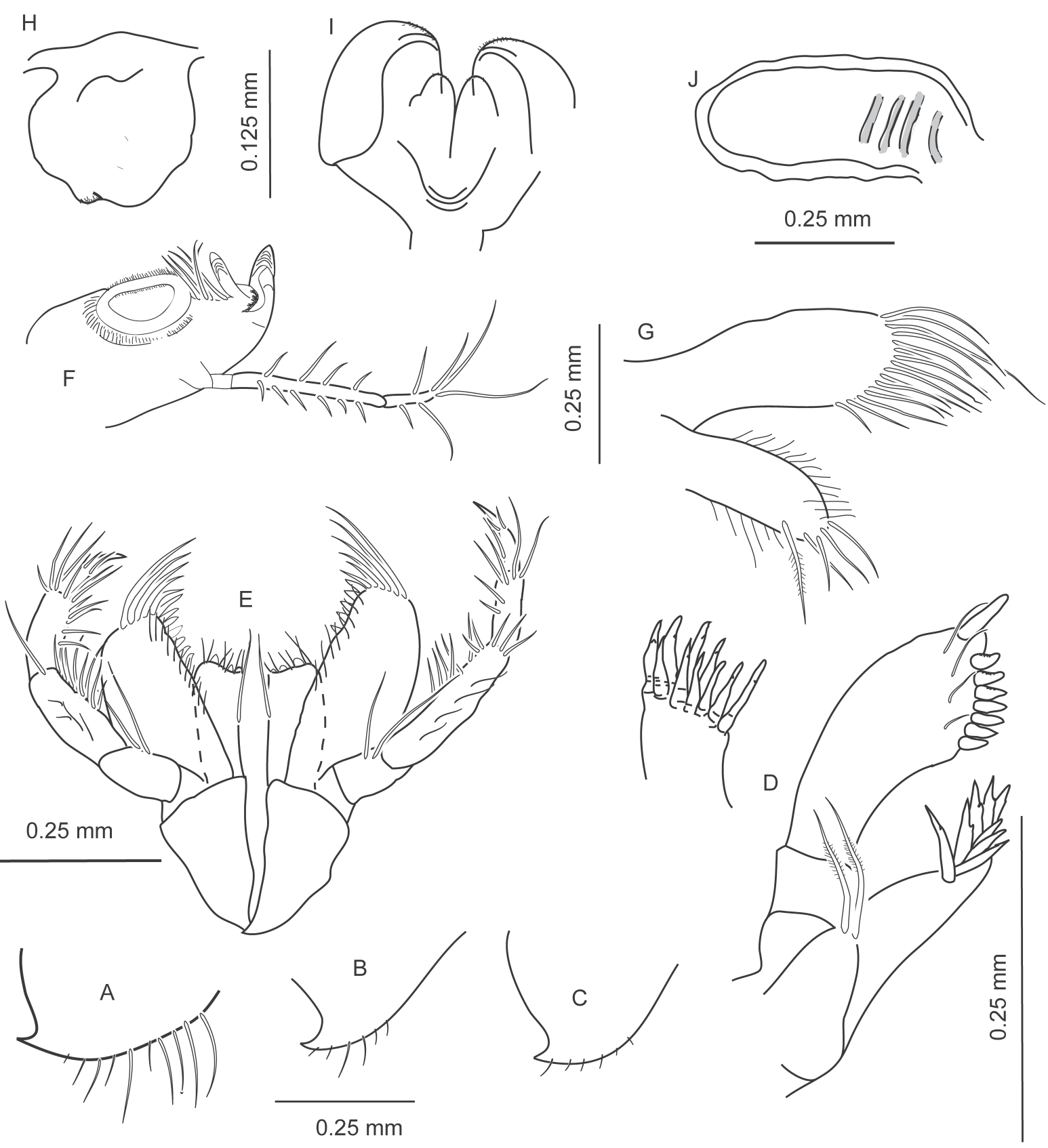

Fig. 14. Lepechinella victoriae sp. nov., holotype, . . A. Right Ep1. B. Right Ep3. C. Right Ep2. D. Right and left Mx1. E. Left and right Mxp. F. Right mandible. G. Left Mx2. H. Upper lip. I. Lower lip. J. Gill of P4. 
Peraeon. All legs long and very slender. Peraeopods 5-7 longer than peraeopods 3-4; peraeopods 3-7 much longer than gnathopods. Gnathopod 1, subchelate and coxal plate 1 biacuminate, the anterior tip $1.5 \mathrm{x}$ posterior; propodus shorter than carpus; basis longer than merus and carpus combined; propodus tapering distally; dactyl curved and $0.5 \mathrm{x}$ propodus; $3-5$ groups of setae on anterior and posterior part of propodus; palm serrulate. Gnathopod 2 subchelate and longer than gnathopod 1; coxal plate 2 tapering to an acute tip; coxal plate 2 with long marginal setae; carpus 1.6x propodus; basis $1.3 \mathrm{x}$ carpus; basis with long setae on posterior margin; carpus and propodus with long setae on both margins; dactylus slender and curved; dactylus shorter than $0.5 x$ propodus; palm serrulate. Coxal plate 3 asymmetric, with long acute anterior process; peraeopod 3 , carpus and propodus of about equal length, shorter than merus and
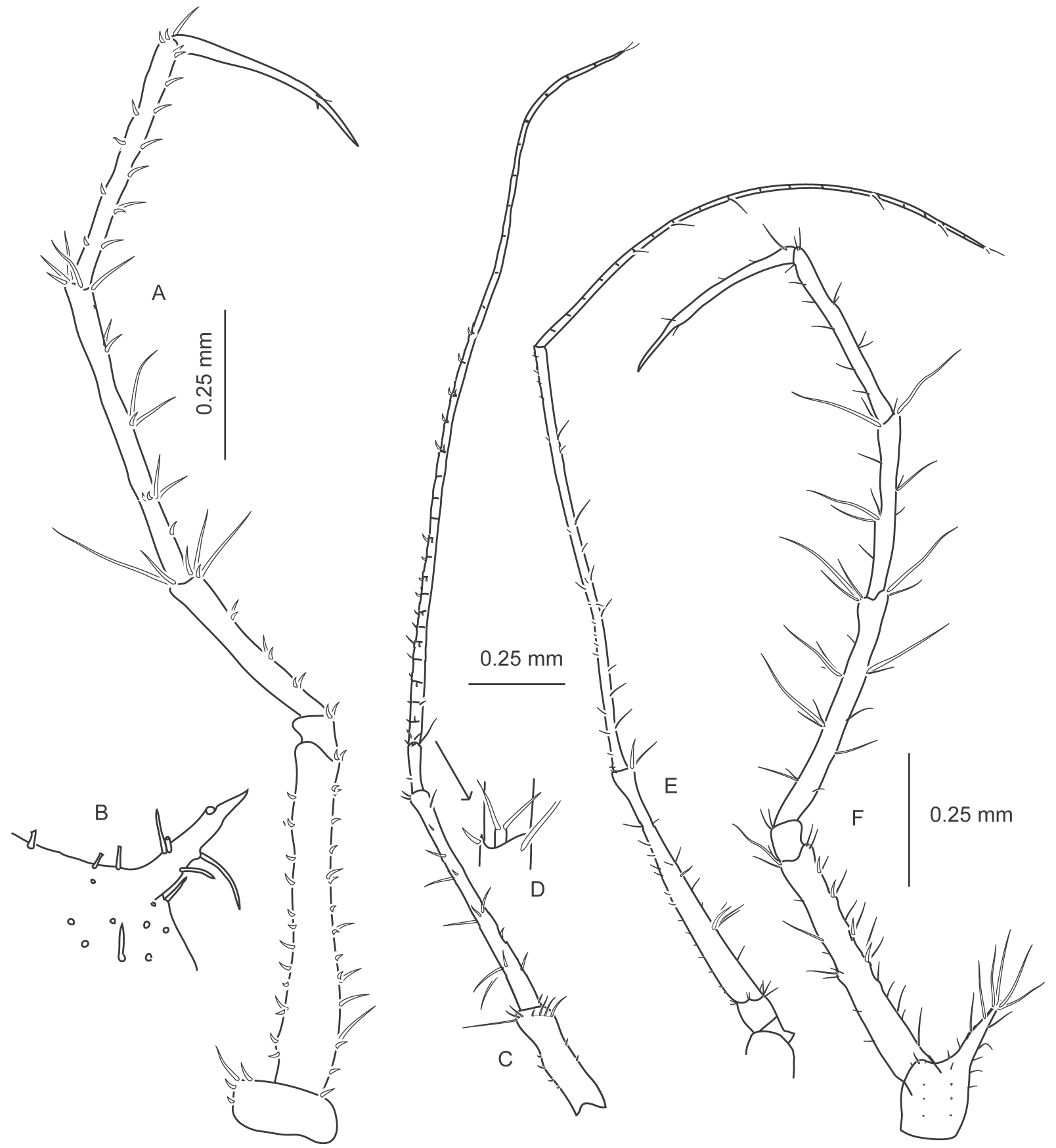

Fig. 15. Lepechinella victoriae sp. nov., holotype, . . A. Left P6. B. Tooth of peraeon segment 7. C. Female A1. D. Accessory flagellum. E. Female A2. F. Left P3. 
basis; dactyl lanceolate, as long as propodus; merus and carpus with long marginal setae. Coxal plate 4 asymmetrically bifid; with long acute anterior process and short blunt posterior process; peraeopod 4, similar to peraeopod 3, but propodus shorter than carpus. Coxal plate 5 rectangular, but with long acute slender anterior process; peraeopod 5, basis and carpus about of equal length, merus much shorter; dactyl lanceolate, slightly shorter than propodus; all articles setose. Coxal plate 6 much wider than high, posterodistal corner subacute, with short setae; peraeopod 6, carpus longer than propodus; merus shorter than either; dactyl lanceolate, slightly shorter than propodus. Coxal plate 7 wider than high, posterodistal corner acute, with short setae; peraeopod 7, basis and carpus of about equal length; propodus shorter, merus much shorter; dactylus lanceolate, slightly shorter than propodus.
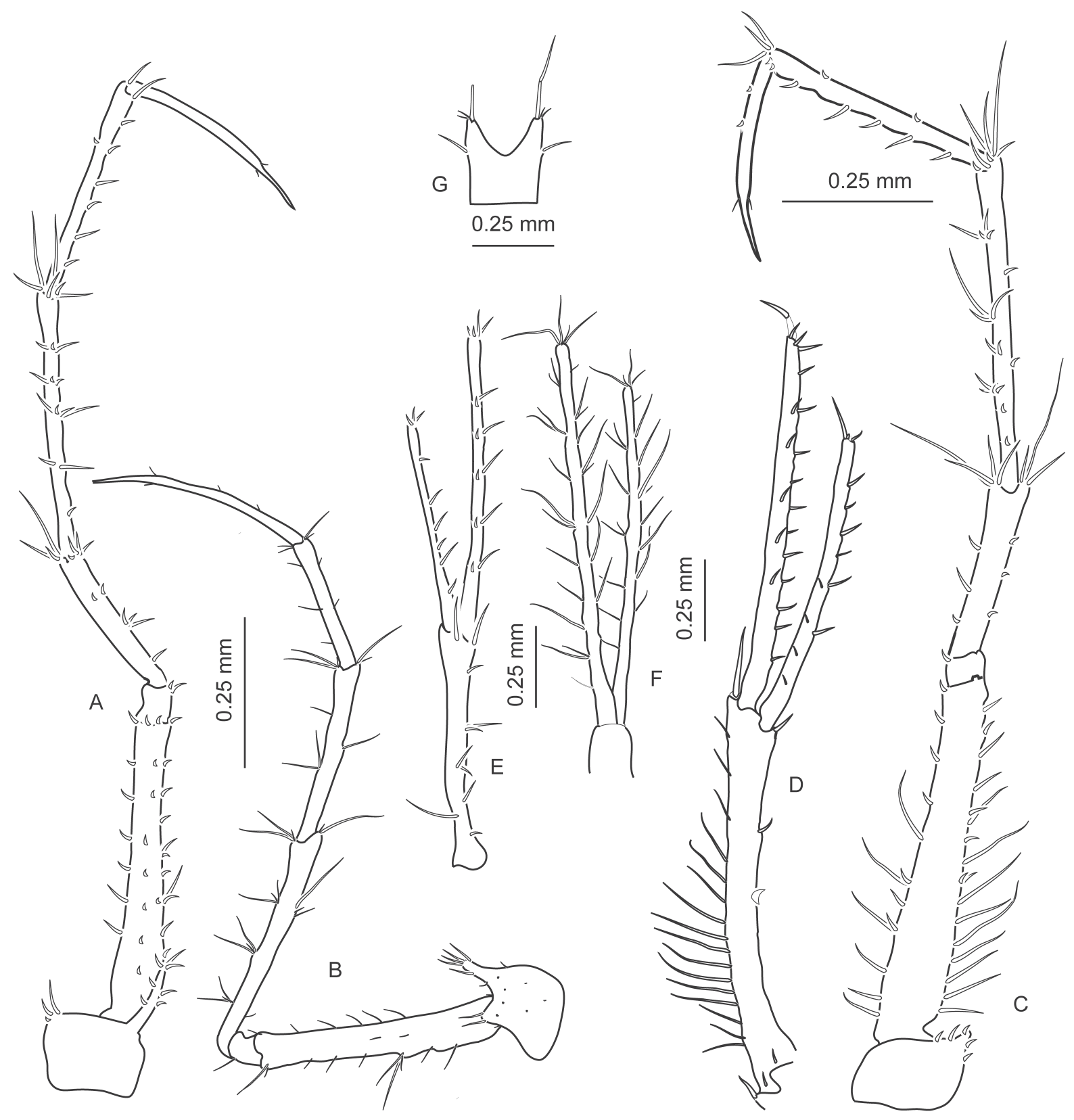

Fig. 16. Lepechinella victoriae sp. nov., holotype, . . A. Left P5. B. Left P4. C. Right P7. D. Right U1. E. Right U2. F. U3. G. Telson. 
Pleon. Subequal in length to peraeon. Pleon segments 1-3 each with one large dorsal tooth at posterior margin; epimeral plates 1-3 similar, with well-developed posterodistal tooth. Urosome shorter than pleon. Urosome segment 1 with large, curved tooth on mid-dorsal margin; urosome segments 2 and 3 fused. Uropods long and slender. Uropod 1, peduncle about as long as outer ramus; inner ramus $0.8 \mathrm{x}$ outer ramus; peduncle with long marginal setae on outer margin, and two distal spines; rami with short spines. Uropod 2, peduncle shorter than inner ramus, but longer than outer ramus, which is $0.7 \mathrm{x}$ inner. Uropod 3, peduncle short and wide, about $1 / 6$ of rami; shorter ramus $0.9 x$ longer, both with long marginal setae. Telson cleft $40 \%$ of total length, with the halves gaping, with acute tips, each with one marginal and one long apical setae, the latter subequal to the length of the telson.

\section{Remarks}

L. victoriae sp. nov. lacks the distinct additional dorsal humps / teeth found in L. schellenbergi, L. norvegica sp. nov. and L. arctica. Peraeopod 4 carpus longer than propodus, while it is the reverse in the three above mentioned species. The anterodistal lobe on coxae $3-5$ is strongly elongated. The gills are proximally pleated. As in $L$. schellenbergi uropod 2 outer ramus is $0.7 \mathrm{x}$ inner, while the ratio is $0.8 \mathrm{x}$ in $L$. norvegica sp. nov. The rostrum is subequal in length to eye lobes, innerlobes of lower lip relatively large as in $L$. grimi and mandible palp article 1 is half the length of article 3.

Genus Lepesubchela gen. nov. urn:1sid:zoobank.org:act:3C6FC751-42FF-41F1-B7A4-D7098D32FB35

\section{Etymology}

The name is a combination of the genus name Lepechinella and the word subchela as the two last subchelate peraeopods are the main characteristic of this genus.

\section{Type species}

Lepesubchela christinae sp. nov.

Lepesubchela christinae sp. nov. urn:1sid:zoobank.org:act:BB597D14-331E-46F2-8C31-52D6BF7977EB

Figs $17-19$

\section{Diagnosis}

Body with teeth on peraeon segments 2-7 and pleon segments 1-4. Urosome segments 2-3 fused. Head without rostrum and postantennal corners, no eyes. Mandible palp present, 3-articulate. Gnathopods 1-2 subchelate; peraeopods 6-7 also clearly subchelate. Uropods with rami well-developed, with many spines.

\section{Etymology}

The species is named after POJ's youngest daughter.

\section{Material examined}

The holotype was collected 4 Jun.1983 at station 83.06.4.1, in the North Atlantic Ocean, southwest of the Faroes and northeast of Rockall (at position 59 $40.4^{\prime} \mathrm{N}, 09^{\circ} 20.6^{\prime} \mathrm{W}$ ). The specimen was sampled at a depth of 1414 meter where the in situ temperature was measured to $4.5^{\circ} \mathrm{C}$. No further material was found. The holotype is deposited in the collections of Zoological Museum in Bergen, Norway under registration no. ZMBN 99136. 
JOHANSEN P.-O. \& VADER W., Lepechinella and Lepesubchela gen. nov. from the North Atlantic

\section{Description}

\section{Holotype}

$4 \mathrm{~mm}$, immature (no external gender characteristics observed).

Body. Sparsely covered with setae that are attached to crown-like pegs. Peraeon segment 1 dorsally smooth; peraeon segments 2-7 and pleon segments 1-4 each with one dorsal tooth. Urosome segments $2-3$ fused. Coxal plates $1-5$ all biacuminate, decreasing in length posteriorly.

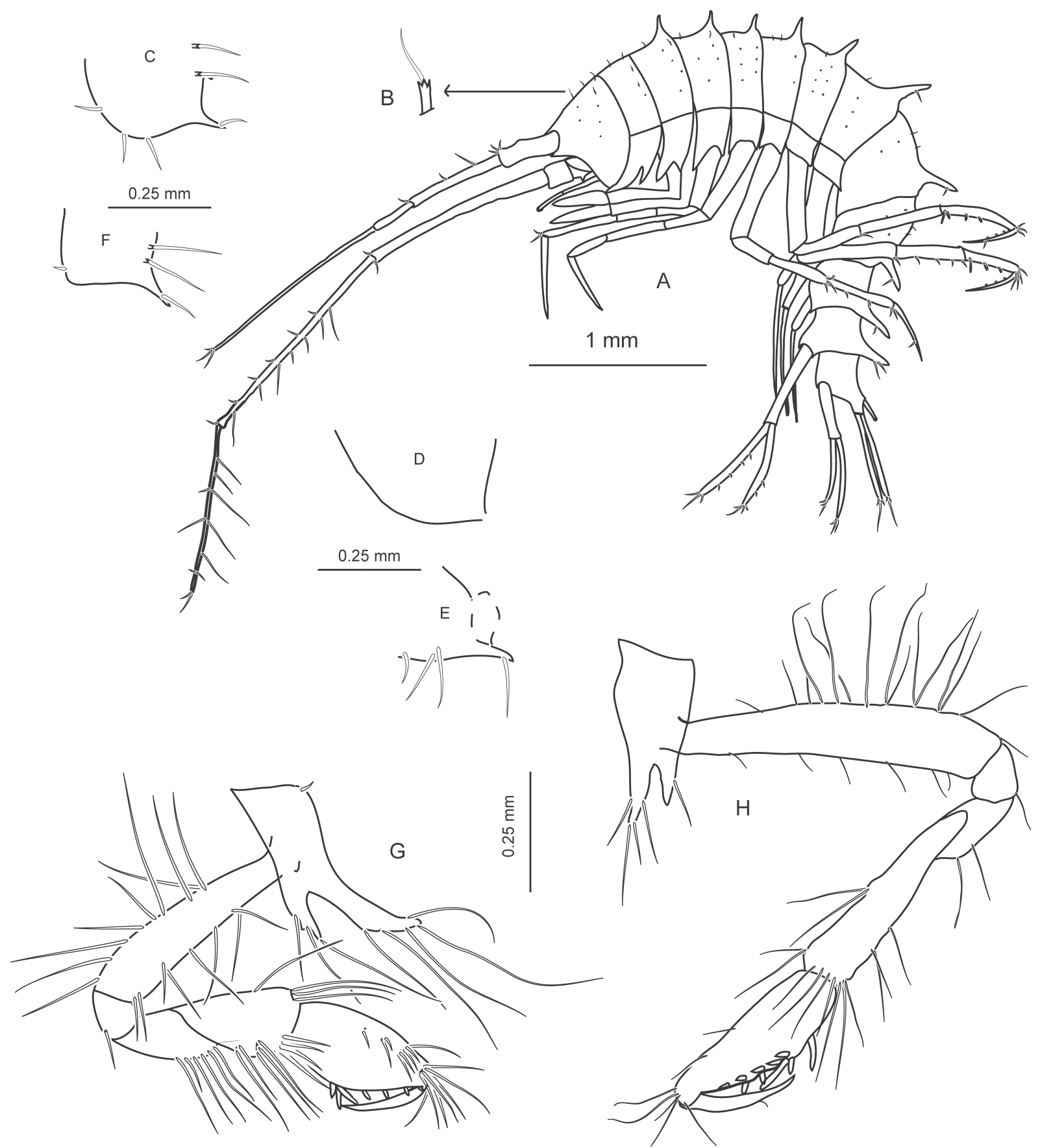

Fig. 17. Lepesubchela christinae gen. et sp. nov., holotype, immature. A. Habitus. B. Setae attached to crown-shaped peg. C. Left Ep1. D-E. Left and right Ep2. F. Left Ep3. G. Right Gn1. H. Left Gn2. 
HEAD. Subequal to peraeon segments $1+2$, no distinct rostrum or postantennal corners; eyes absent or at least indistinct in alcohol, an invagination at the basis of antenna 2 . Antenna 1 , peduncle article 1 broader than article 2 and 3; peduncle article 2 is $2 \mathrm{x}$ as long as article 1 ; peduncle article 3 is $0.5 \mathrm{x}$ art 1 ; accessory flagellum is 1 -articulate with three apical setae; flagellum slightly longer than peduncle articles 1-3 combined; flagellum 12-articulate. Antenna 2 is $1.5 x$ antenna 1 . Antenna 2, peduncle articles 4 and 5 long, subequal; flagellum shorter than article 5; flagellum 6-articulate.

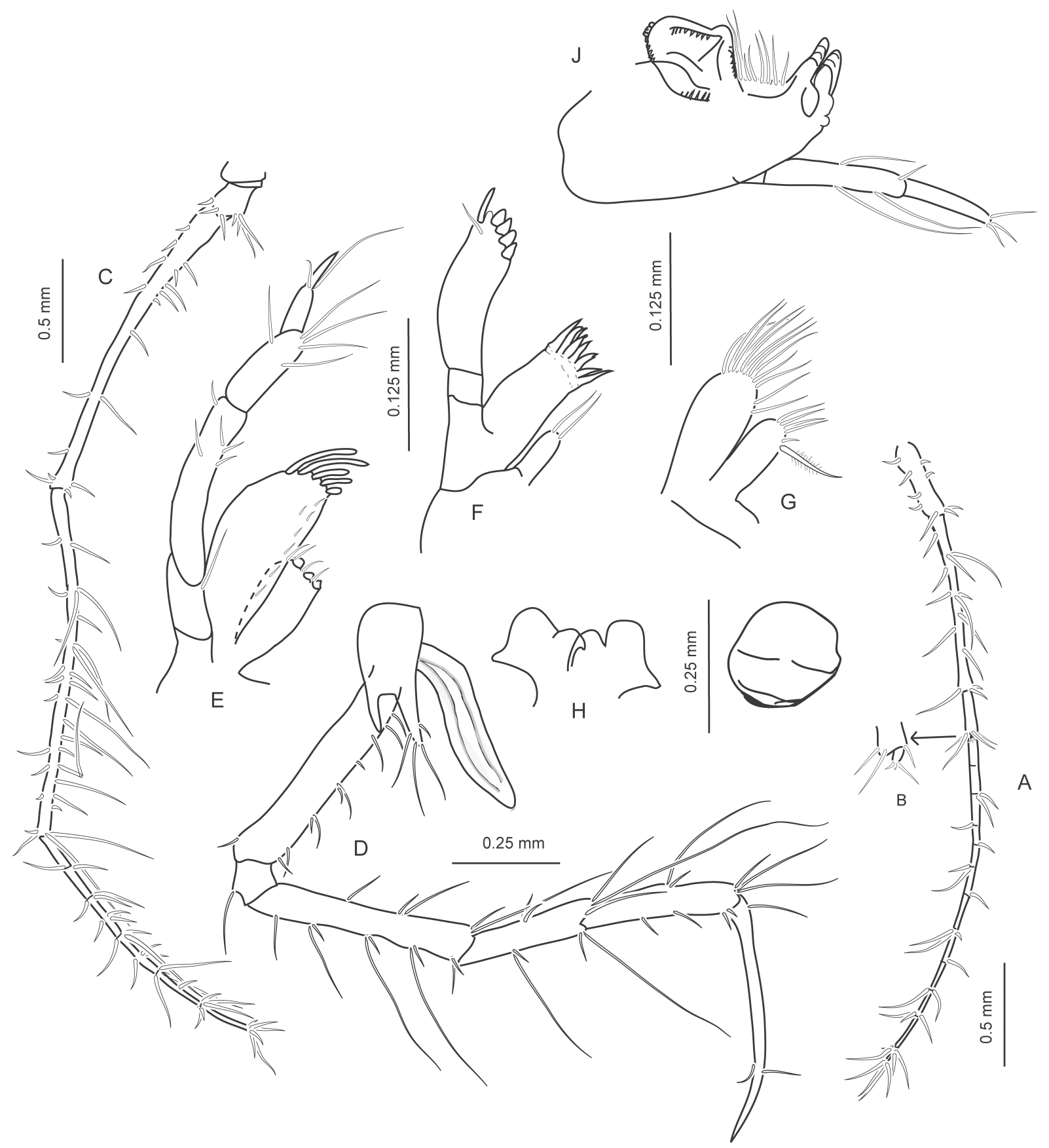

Fig. 18. Lepesubchela christinae gen. et sp. nov., holotype, immature. A-B. A1 with accessory flagellum. C. A2. D. Right P3 with gill. E. Left Mxp. F. Left Mx1. G. Left Mx2. H. Lower lip. I. Upper lip. J. Right mandible. 
JOHANSEN P.-O. \& VADER W., Lepechinella and Lepesubchela gen. nov. from the North Atlantic

MOUTHPARTS. Upper lip circular; lower lip inner lobe $3 / 4$ of outer; mandible with lacinia mobilis as long as incisor, both armed with denticles; 7-8 accessory setae; molar elevated, trapezoid with rounded angles. Palp 3-articulate; article 2 the longest, $1.5 \mathrm{x}$ article 3 and $4.5 \mathrm{x}$ article 1; article 3 tapering, with 3 apical setae. Maxilla 1, inner plate narrow with 2 long apical setae; outer plate with 8 serrate spine teeth; palp 2 -articulate; article 2 slightly obliquely truncate, with 4 blunt and 1 apical long spine. Maxilla 2, inner plate shorter and narrower than outer plate; inner plate with 1 strong plumose and a few simple setae; outer plate with 12 medial and apical setae. Maxilliped, inner plate apically with 3 blunt spines and a few

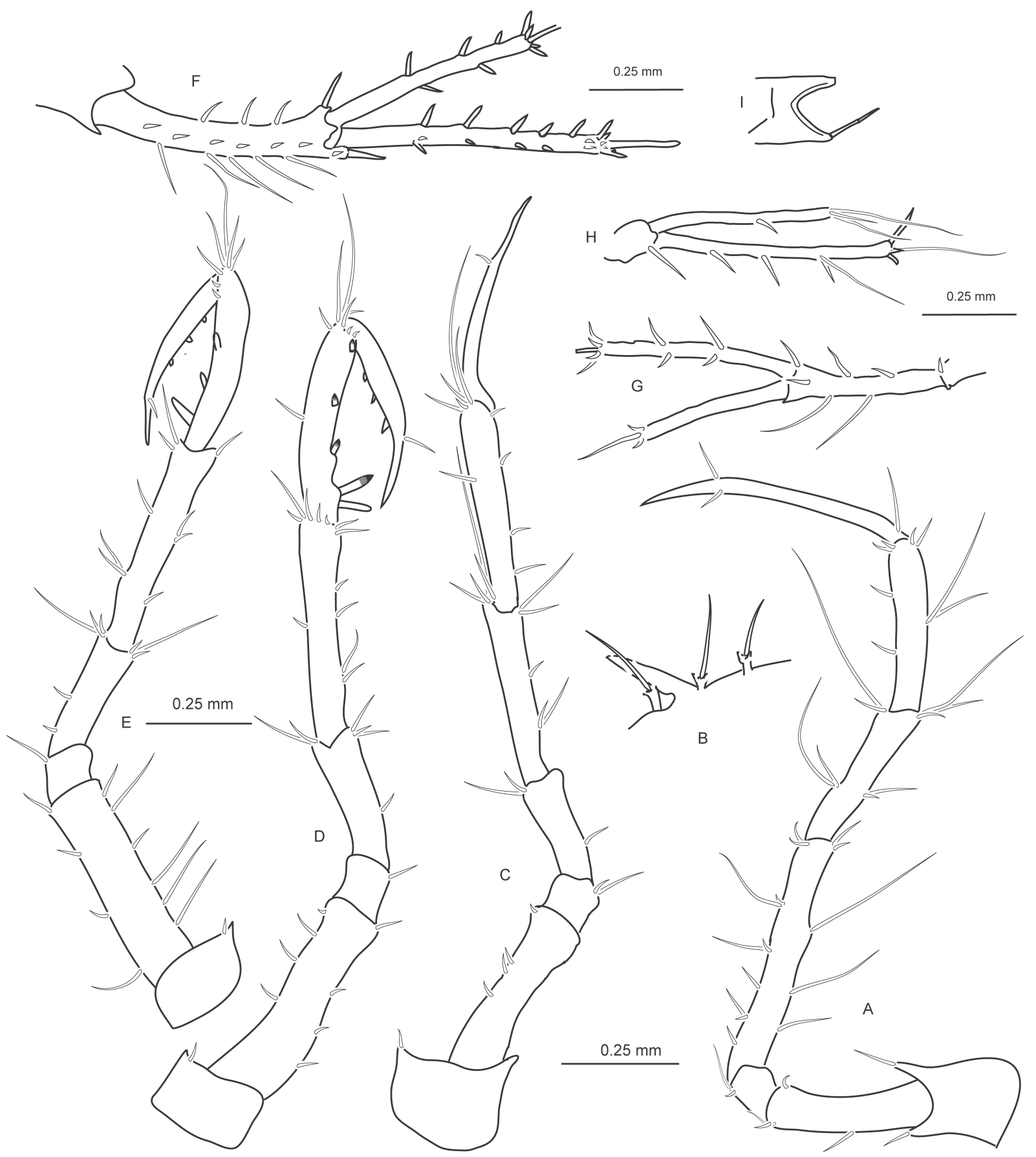

Fig. 19. Lepesubchela christinae gen. et sp. nov., holotype, immature. A. Left P4. B. Tooth of peraeon segment 5. C. Left P5. D. Left P6. E. Right P7. F. Left U1. G. Right U2. H. U3. I. Telson. 
setae, inner plate $0.6 x$ outer plate; outer plate with 5 slender apical spine teeth of varying length; palp 4 -articulate, article 2 as long as articles $3+4$ combined.

Peraeon. Gills smooth, long and narrow. Gnathopod 1, subchelate and quite stout (for a lepechinellid); coxal plate 1 asymmetrically bifid with anterior process twice as long as posterior, both with a serrate edge; basis tapering proximally, slightly longer than merus and carpus combined; propodus oval, with four groups of medial setae; palm slightly longer than posterior margin, with marginal spines and a cluster of spines delimiting the palmar corner. Gnathopod 2 longer and more slender than gnathopod 1; gnathopod 2 subchelate; coxal plate 2 asymmetrically bifid with acute lobes; merus short; carpus slightly longer than propodus; propodus oblong; palm straight, oblique, slightly longer than posterior border, with many and strong marginal spines. Coxal plate 3 higher than broad, asymmetrically bifid, with anterior lobe longest; merus longer than carpus and propodus; dactyl lanceolate and as long as carpus and propodus combined. Coxal plate 4 higher than broad, asymmetrically bifid; merus longer than carpus and propodus; merus subequal to lanceolate dactyl. Coxal plate 5 broader than high, biacuminate; carpus subequal to basis and longer than merus; dactylus lanceolate, as long as propodus. Peraeopod 6 clearly subchelate; coxal plate 6 rectangular with posterodistal corner acute; merus shorter than carpus; basis subequal to carpus; propodus and dactylus stout and subequal in length, both with strong blunt marginal spines. Peraeopod 7 clearly subchelate; coxal plate 7 lemon-shaped with posterodistal corner acute; basis subequal to carpus; merus shorter than carpus; propodus and dactylus stout and subequal in length, with strong blunt marginal spines.

Pleon. Epimeral plates 1-3 each with a strong acute posterodistal tooth. Uropod 1 peduncle armed with two distal and several lateral spines; peduncle subequal in length to outer ramus; inner ramus $0.8 \mathrm{x}$ outer ramus; both peduncle and rami heavily spinose. Urosome segments $2-3$ fused. Uropod 2 peduncle subequal to outer ramus; outer ramus $0.8 \mathrm{x}$ inner; inner ramus with strong marginal spines. Uropod 3 peduncle short and wide, $1 / 3$ to $1 / 4$ of rami; rami with marginal spines and apical setae. Telson cleft to about half of total length, halves widely gaping, with long apical setae.

\section{Remarks}

Lepesubchela christinae gen. et sp. nov. is characterized by setae attached to crown-shaped pegs on the body; Rostrum and dorsal teeth on peraeon segment 1 is absent. The species has an invagination at the basis of antenna 2 and is lacking postantennal corners as in Lepechinelloides karii Thurston, 1980. Coxal plates 1-5 biacuminate. Antenna 2 peduncle article 5 longer than flagellum. Posterodistal angle of epimeral plates 1-3 without sinus and strongly acute. Gnathopods 1 and 2, peraeopods 6 and 7 subchelate and armed with strong teeth. The mandible molar is special and looks like a trapezoid with spine-like margins. Lower lip of $L$. christinae gen. et sp. nov. resembles the lower lip of $L$. skarphedini and upper lip, maxilliped, maxilla 1 and 2 are similar to several Lepechinella species.

The family Lepechinellidae consists of a single speciose genus, Lepechinella, and a number of small genera, that in most cases vary in only one or two apomorphies. The new genus Lepesubchela similarly is primarily distinguished by a single strong autapomorphy, the prehensile posterior peraeopods, although also the morphology of the head is deviant. Whether these different autapomorphies really delimit independent evolutionary lines, can only be decided on the base of a cladistic analysis preferably including molecular data.

\section{Discussion}

Since most of the Lepechinellidae species are known from single localities and few specimens only, the nature and degree of allometry and intraspecific variation is poorly understood (Thurston 1980a). Most species seem sufficiently distinct to be fairly readily separable. This is not true, however, for the six species in the L. chrysotheras group. All of these are very similar in body morphology and differ only 
JOHANSEN P.-O. \& VADER W., Lepechinella and Lepesubchela gen. nov. from the North Atlantic

in small and rather subtle characters. More material will be required to understand the true nature of the components of this group (op. cit.). As a consequence of the dearth of qualitative characters, many of the specific differences now attributed to species of Lepechinella are for a large part quantitative (J.L. Barnard 1973). This author concluded that because of the early stage of exploration of the genus, referral to morphs as distinct species may be justified, until more is learned about morphological variations and geography of speciation in Lepechinella. A change in species composition on each side of the Greenland-Iceland-Faroe Ridge has been observed for hyperbenthic amphipods in the families Eusiridae and Calliopiidae (Weisshappel 2000, 2001). The thermohaline characteristics of the deep sea water masses on both sides are very different and the ridge acts as a barrier for deep sea species. Most of the Lepechinella species probably have a benthic lifestyle and are thus less mobile than pelagic species and endemic species with restricted distributional range may be expected.

Most of the previously described Lepechinella species from different parts of the world have a rounded or monoacuminate ventral part of the coxal plate 1: L. aberrantis J.L. Barnard, 1962; L. bieri J.L. Barnard, 1957; L. cachi J.L. Barnard, 1973; L. campensis Sittrop \& Serejo, 2009; L. cetrata K.H. Barnard, 1932; L. cura J.L. Barnard, 1973; L. curvispinosa Pirlot, 1933; L. drygalski Schellenberg, 1926; L. huaco J.L. Barnard, 1973; L. laurensi Sittrop \& Serejo, 2009; L. madagascariensis Ledoyer, 1982; L. monocuspidata J.L. Barnard, 1961; L. occlo J.L. Barnard, 1973; L. pangola J.L. Barnard, 1962; L. raua J.L. Barnard, 1973; L. sagamiensis Gamo, 1981; L. sucia J.L. Barnard, 1961; L. uchu J.L. Barnard, 1973; L. ultraabyssalis Birstein \& Vinogradova, 1960; L. vitrea Kamenskaya, 1977; L. wolffi Dahl, 1959.

Barnard (1973) provided a phyletic key to the species of Lepechinella. The group that is characterized by strongly dentate peraeon segments, a bidentate peraeon segment 1 and a bifid coxa 1 comprises L. chrysotheras, L. arctica, L. turpis, L. eupraxiella and L. manco. L. helgii (op.cit.). L. victoriae sp. nov., $L$. norvegica sp. nov. and $L$. schellenbergi also fits in the same lepechinellid group. These are all Atlantic and Arctic species with the exception of $L$. turpis which is described from Baja California. $L$. auca J.L. Barnard, 1973, and L. hirsuta from the coasts of Chile and Brasil, respectively, also have a bifid coxal plate 1, but lack teeth on peraeon segment 1. Three other North Atlantic species are not included in this phyletic group: L. skarphedini has one dorsal tooth on peraeon segment 1 , L. echinata has a slim monoacuminate angle on coxa 1 and $L$. grimi has a slipper-shaped coxal plate 1 .

The shape of the coxae and the number and presence of dorsal teeth, among others, are used in the key of Lepechinella from the Atlantic and the Arctic we provide here. L. victoriae sp. nov. lacks accessory dorsal teeth. L. chrysotheras, L. turpis, L. manco and L.helgii have several accessory teeth in front of the main posterior dorsal tooth on pleon segments 1-3, while $L$. arctica, $L$. schellenbergi, $L$. norvegica sp. nov. and L. eupraxiella have one accessory tooth. L. eupraxiella has also a short rostrum, hook-like processes at posterodistal angles of epimeral plates, bifid shape of coxal plate 1 and an anterior directed hook on coxal plate 6 .

\section{Acknowledgements}

We thank Krzysztof Jażdżewski (University of Łódź, Poland) for valuable help in translation from a Russian publication, Charles Oliver Coleman (Museum für Naturkunde, Berlin) for obtaining material from the Römer \& Schaudinn Expedition, Michael Thurston (University of Southampton, UK) for help during the work, Jørgen Oleson (Zoological Museum in Copenhagen) for obtaining material from the Ingolf Expediton and Egor Vinogradov for sending a Russian paper and providing information on it. 


\section{References}

Andres H.G. \& Brandt A. 2001. Lepechinellid genera Paralepechinella Pirlot, 1933 and Lepechinelloides Thurston, 1980: First records from Antarctica (Crustacea: Amphipoda). Mitteilungen aus dem Naturhistorischen Museum in Hamburg 98: 77-97.

Barnard J. L. 1973. Deep-sea Amphipoda of the Genus Lepechinella (Crustacea). Smithsonian Contributions to Zoology 133, Smithonian Institution Press, Washington. http://dx.doi.org/10.5479/ $\underline{\text { si.00810282.133 }}$

Barnard J. L. \& Karaman G.S. 1991. The families and genera of marine gammaridean Amphipoda (except marine gammaroids). Records of the Australian Museum 13, Australian Museum, Sydney.

Bousfield E. L. \& Kendall I. A. 1994. The amphipod superfamily Dexaminoidea on the North American Pacific coast; families Atylidae and Dexaminidae: systematics and distributional ecology. Amphipacifica $1(3): 3-66$.

Chevreux E. 1914. Diagnoses d'Amphipodes Nouveaux Provenant des Campagnes de la PrincesseAlice dans l'Atlantique nord. Bulletin de l'Institut Océanographique, Monaco 296: 1-4.

Coleman C.O. 2003. "Digital inking": How to make perfect line drawings on computers. Organisms Diversity \& Evolution 3 Electr. Suppl. 14: 1-14.

Coleman C.O. 2006. Substituting time consuming pencil drawings in arthropod taxonomy using stacks of digital photographs. Zootaxa 1360: 61-68.

Coleman, C.O. 2009. Drawing setae the digital way. Zoosystematics and Evolution 85 (2): 305-310. http://dx.doi.org/10.1002/zoos.200900008

Gurjanova E.F. 1951. Bokoplavy Morei SSSR i Sopredel'nykh Vod. (Amphipoda-Gammaridea). Izd. Akademia Nauk SSSR, Moscow \& Leningrad.

Kamenskaya O.E. 1995. Gammaridean Amphipods from hadal trenches of the Pacific Ocean. Polskie Archiwum Hydrobiologii 42 (4): 327-334.

Schellenberg A. 1925. Die Gammariden Spitzbergens nebst einer Übersicht der von Römer \& Schaudinn 1898 im Nördlichen Eismeer Gesammelten Arten. Mittheilungen Zoologisches Museum in Berlin 11: 195-231.

Schellenberg A. 1926. Die Gammariden der Deutschen Südpolar-Expedition 1901-1903. Deutsche Südpolar-Expedition 18: 235-414.

Sittrop D.J.P. \& Serejo C.S. 2009. Three species of the genus Lepechinella (Amphipoda: Gammaridea: Lepechinellidae) collected from Campos Basin slope, RJ, Brasil. Scientia Marina 73 (3): 473-485. http://dx.doi.org/10.3989/scimar.2009.73n3473

Stebbing T. R. R. 1908. On two new Species of Northern Amphipoda. Journal of Linnean Society London, Zoology 30: 191-197. http://dx.doi.org/10.1111/j.1096-3642.1908.tb02133.x

Stephensen K. 1938. The amphipoda of Northern Norway and Spitzbergen with adjacent waters. Tromsø museums skrifter Vol III Part II: 141-278.

Stephensen K. 1944. Crustacea Malacostraca VIII (Amphipoda IV). Danish Ingolf-Expedition 3 (13): $1-51$.

Thurston M. H. 1980a. Abyssal benthic Amphipoda (Crustacea) from the East Iceland Basin 2. Lepechinella and an allied new genus. Bulletin British Museum of Natural History (Zoology) 38 (1): 69-87. 
JOHANSEN P.-O. \& VADER W., Lepechinella and Lepesubchela gen. nov. from the North Atlantic

Thurston M. H. 1980b. Abyssal benthic Amphipoda (Crustacea) from the East Iceland Basin 1. The genus Rhachotropis. Bulletin British Museum of Natural History (Zoology) 38 (1): $43-67$.

Weisshappel J.B. 2000. Distribution and diversity of the hyperbenthic amphipod family Eusiridae in the different seas around the Greenland-Iceland-Faroe ridge. Sarsia 85: 227-236.

Weisshappel J.B. 2001. Distribution and diversity of the hyperbenthic amphipod family Calliopiidae in the different seas around the Greenland-Iceland-Faroe ridge. Sarsia 86: 143-151.

Manuscript received: 1 December 2014

Manuscript accepted: 25 March 2015

Published on: 29 June 2015

Topic editor: Rudy Jocqué

Desk editor: Kristiaan Hoedemakers

Printed versions of all papers are also deposited in the libraries of the institutes that are members of the EJT consortium: Muséum National d'Histoire Naturelle, Paris, France; Botanic Garden Meise, Belgium; Royal Museum for Central Africa, Tervuren, Belgium; Natural History Museum, London, United Kingdom; Royal Belgian Institute of Natural Sciences, Brussels, Belgium; Natural History Museum of Denmark, Copenhagen, Denmark. 